\title{
Disruption of mesoderm and axis formation in fish by ectopic expression of activin variants: the role of maternal activin
}

\author{
Joachim Wittbrodt and Frédéric M. Rosa ${ }^{1}$ \\ Biocenter of the University of Basel, Department of Cell Biology, CH-4056 Basel, Switzerland
}

Formation of mesoderm in Xenopus embryos is the result of an induction event in which peptides such as FGF or activins have been implicated. It was recently demonstrated, by the ectopic expression of a truncated activin receptor, that activin receptor signaling pathways are involved in the processes of mesoderm and axis formation in vivo. However, this approach does not directly address the role of activin itself nor the involvement of activins in the formation of mesoderm in embryos from other vertebrates. In addition, activins are expressed maternally as a protein component of the egg as well as transcribed zygotically, and it is not clear which of the two forms is involved in mesoderm formation. To address those three issues, we analyzed the role of activins in the development of fish embryos by generating two activin dominant-negative variants. One of the variants behaves as an inhibitor of activin protein. The second variant was found to deplete the activin pool when cotranslated with wild-type activin. Injection of RNA encoding these variants into the two-cell embryo of the small teleost fish Oryzias latipes (Japanese medaka) demonstrates that only the maternally provided activin protein is required for mesoderm and axis formation in fish in vivo.

[Key Words: Medaka; zebrafish; mesoderm induction; activin; dominant-negative variant]

Received December 24, 1993; revised version accepted May 2, 1994.

Vertebrate embryos rely heavily on cell-cell interactions to generate a structured animal from a radially symmetric egg. In particular, induction is the process during which a population of cells emits a signal that will change the fate and/or behavior of neighboring target cells. In amphibian embryos, mesoderm derives from the marginal zone ectoderm under the influence of inducing signal(s) emanating from the endoderm (Nieuwkoop 1973). Mesoderm, in turn, plays an important role in the organization of the body axis. The dorsal region of the newly induced germ layer, the organizer, can induce a secondary body axis after transplantation in amphibia (Spemann and Mangold 1924) and in fish (Luther 1935). Analysis of mesoderm induction for the last 70 years suggested that at least three types of signals emerging from the vegetal half of the embryo or localized in the marginal zone are required for mesoderm induction (for review, see Kimelman et al. 1992). The nature of a signal localized in the marginal zone is probably a factor with a Wnt-like activity (for review, see Kimelman et al. 1992) or is noggin (Smith and Harland 1992). These factors do not induce mesoderm (Smith and Harland 1991, 1992) but may act as dorsalising potentiators (Smith et al. 1993). All of them rescue normal axis formation in Xe-

${ }^{1}$ Present address: U368 INSERM, Ecole Normale Supérieure, 75230 Paris Cedex 05, France. nopus embryos ventralized by UV irradiation during the first cell cycle.

Polypeptide growth factors encoded by two different gene families, the fibroblast growth factor (FGF) family (Kimelman et al. 1988; Slack et al. 1987; Isaacs et al. 1992 ) and the transforming growth factor- $\beta$ (TGF- $\beta$ ) family [activin (Asashima et al. 1990; Smith et al. 1990; Vale et al. 1990); bone morphogenetic protein 4 (BMP-4; Köster et al. 1991); Vg1 (Weeks and Melton 1987)] formally fulfill most of the criteria for a mesoderm inducer. The genes encode proteins carrying a signal peptide for secretion. Either mRNA [XeFGF (Isaacs et al. 1992); BMP-4 (Köster et al. 1991; Dale et al. 1992; Jones et al. 1992)] or proteins [FGF (Slack et al. 1987; Kimelman et al. 1988); activins (Asashima et al. 1991; Ge et al. 1993a); Vgl [Weeks and Melton 1987)] have been detected prior or coincident with mesoderm induction in vivo (as mater$\mathrm{nal}$ and/or zygotic components|. In addition, Vgl mRNA is localized in the prospective endoderm (Weeks and Melton 1987). XeFGF, activin, and BMP-4 induce mesodermal structures in vitro or induce the formation of axial structures upon injection of their RNA into ventral blastomeres of the early Xenopus blastula. The carboxyterminal part of $\mathrm{Vg} 1$ will induce mesoderm only if properly processed, as suggested by the use of $\mathrm{BMP}-\mathrm{Vg} 1$ chimeric RNA (Dale et al. 1993; Thomsen and Melton 1993).

Quite strikingly, activins induce a wide variety of me- 
soderm derivative in a dose-dependent fashion. Sharp thresholds of activin concentrations induce the distinct expression of mesodermal markers in Xenopus animal cap cells. Low concentrations of activin induce the expression of ventral-posterior markers whereas high concentrations induce dorsal-anterior markers (Green et al. 1992). The presence of an activin concentration gradient along the dorsoventral axis of the amphibian embryo endoderm would be sufficient to explain the inducing properties of the early endoderm and its involvement in the patterning of the primary mesoderm as suggested by Green et al. (1992).

The involvement of activins and FGF in mesoderm induction in vivo has been analyzed by interfering with downstream components of the signaling pathways, for example, with their receptors. Injection of RNA encoding a dominant-negative FGF receptor into Xenopus embryos prevented the formation of ventral-posterior mesodermal structures, suggesting that a member of the FGF family serves as an inducer for ventral posterior mesoderm (Amaya et al. 1991). As well, injection of high amounts of a truncated form (Hemmati-Brivanlou and Melton 1992) of one of the four known Xenopus activin receptors (XAR1; Nishimatsu et al. 1992) led to a significant reduction in the expression of mesodermal structures and markers, including the most dorsal-anterior ones (Hemmati-Brivanlou and Melton 1992). This suggests a role for the XAR1 activin receptor signaling pathway in the establishment of mesoderm. Although other activin receptors are expressed maternally, their involvement remains unclear (Nishimatsu et al. 1992).

Experiments relying on truncated receptors provide only indirect evidence for FGF or activin involvement, as these receptors might interfere with related pathways as well. A direct analysis of the role of activins in vivo necessitates interference with the activity of the endogenous activins. This could be achieved either by deleting or mutating the endogenous genes or by a specific dominant-negative interaction (Herskowitz 1987) blocking the wild-type activity in the developing embryo. The latter approach could also distinguish between maternal versus zygotic activin contributions.

We chose a small freshwater fish, the Japanese medaka (Oryzias latipes) to investigate the role of activin in mesoderm induction and axis formation in lower vertebrates. In addition to the advantages known for other small egg-laying fish (e.g., fundulus, zebrafish), stable transgenics can be generated with medaka that express their transgenes after injection into the germinal vesicle (Ozato et al. 1986). Although mesoderm induction has not been analyzed in such detail in fish, the factors and the mechanism involved in embryonic induction in fish appear to be quite similar to those in higher vertebrates. The transplantation of the archenteron roof in trout induces the formation of a secondary body axis (Luther 1934). The zebrafish embryonic shield transplanted to Triturus blastulae acts as an organizer across species borders (Oppenheimer 1936). Expression of mesodermal markers, for example, of Brachyury, is localized in homologous regions of the fate map in fish and Xenopus. In explanted animal caps the expression of Brachyury, as an immediate marker for mesoderm induction, is induced by activins in zebrafish (Schulte-Merker et al. 1993) as well as in Xenopus (Smith et al. 1991).

Activins are active as homo- or heterodimers formed after dimerization of the two known activin $\beta$-chains (activin $\beta A$ and $\beta B$ ). To obtain their inducing potential, the highly conserved carboxy-terminal region must be cleaved off and then released from the amino-terminal remainder (for review, see Vale et al. 1990). On that basis, we generated dominant-negative fish activin variants. One variant inhibiting wild-type activin allowed us to determine the role of maternally provided activin protein. The role of the zygotically expressed activin was analyzed with a variant that acts upon cotranslation. The results of our experiments demonstrate that only the maternally provided activin protein is required for the induction of mesoderm and axis formation. Furthermore, embryos expressing an increasing dose of dominant-negative variant progressively lose dorsal-anterior structures.

\section{Results}

\section{Isolation of fish activin cDNA}

Partial sequences representing the carboxy-terminal portions of activin chains were amplified from medaka and zebrafish genomic DNA by the polymerase chain reaction (PCR). Clones highly homologous to activin $\beta A$ $\left(\beta A_{1}\right.$ and $\left.\beta A_{2}\right)$ and $\beta B$ from higher vertebrates were obtained from medaka and zebrafish. The sequences of the activin peptides encoded by the PCR fragments homologous to $\beta B$ are shown in Figure 1 . The deduced medaka and zebrafish $\beta B$ amino acid sequences share $92 \%$ identity. A zebrafish activin $\beta B$ cDNA (Zact $\beta B$ ) was isolated from a cDNA library established from 1-day-old embryos. Zact $\beta B$ encodes a protein with $73 \%$ overall identity to mammalian activin $\beta B$, including all of the evolutionary conserved residues. The encoded protein contains a putative signal peptide for secretion and a tribasic region preceding the conserved carboxyl terminus, which is expected to serve as a proteolytic processing site for the release of the active carboxy-terminal peptide.

\section{Expression}

The expression of the medaka activin $\beta B$ gene was analyzed by Northern blot assays (data not shown). A 2.3-kb transcript was detected in ovary and testis as expected (Vale et al. 1990). No activin transcript could be found in early embryos. We therefore used reverse transcriptasepolymerase chain reaction (RT-PCR) to increase the sensitivity of detection. Expression of activin $\beta B$ was assayed with specific primers that amplify a 264-bp fragment. Southern blots of the PCR products were hybridized with the corresponding medaka probe under high stringency. RT-PCR performed with RNA from staged embryos shows that $\beta B$ mRNA first appears in late blas- 


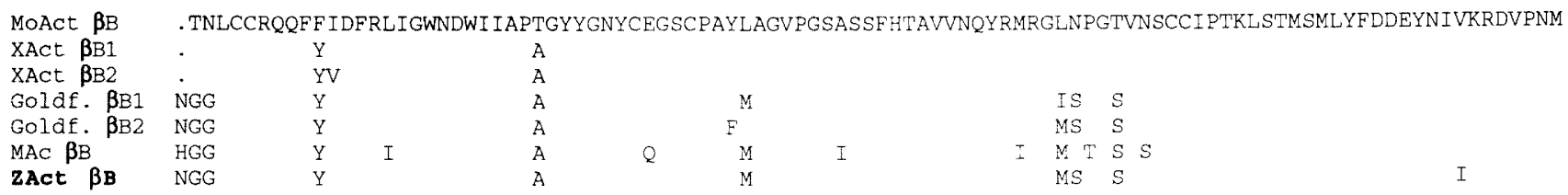

Figure 1. Comparison of carboxy-terminal sequences of the medaka and zebrafish activin $\beta B$ to other vertebrates as deduced from PCR-amplified fragments. The protein sequence of mouse activin $\beta B$ (MoAct $\beta B$; Albano et al. 1993) is compared with the Xenopus activin (Xact $\beta B 1$, $\beta B 2$; Thomsen et al. 1990), goldfish (Goldf. $\beta B 1, \beta B 2$; Ge et al. 1993b) medaka (Mac $\beta B$ ), and zebrafish $(Z a c t ~ \beta B)$ activin $\beta B$ sequences. Blanks indicate identical amino acids; gaps introduced for a better alignment are represented by a dot. Flanking regions encoded by the PCR primers are not shown. Carboxy-terminal sequences deduced from the from the full-length cDNA clone and the Zact $\beta B$ PCR product are identical.

tula (stage 12) (Fig. 2) and persists during later embryonic stages. In adult tissues activin $\beta B$ mRNA was detected by RT-PCR in ovary and testis, as well as in the brain (Fig. 2), as expected. Transcripts of activin $\beta A_{1}$ and $\beta A_{2}$ were also found in ovary and testis, but during embryogenesis their expression was first detected in the late gastrula (data not shown).

The temporal and spatial distribution of activin protein during embryogenesis was determined with the $\mathrm{E} 4$ monoclonal antibody $(\mathrm{mAb})$ directed against a peptide derived from human activin A (Groome and Lawrence 1991) but able to recognize both mouse activins A and B (Albano et al. 1993). On medaka ovary sections, the mAb E4 labeled primarily the cytoplasm of early oocytes as well as the germinal vesicle of large oocytes and follicle cells, confirming results from Ge et al. (1993a; data not shown). The same mAb was used to stain whole-mount preparations of early medaka embryos. Staining was detected from the one-cell stage until at least the blastula stage (Fig. 3). Preincubation of the mAb E4 with the supernatant from $\mathrm{pC} \beta B$ transfected 293 cells /see Materials

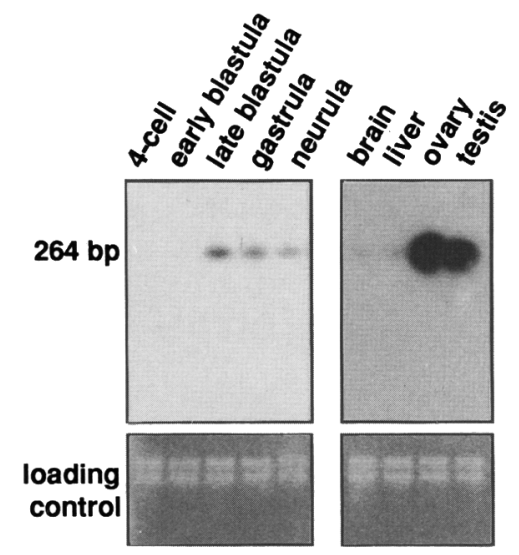

Figure 2. Analysis of activin $\beta B$ expression during medaka embryogenesis by RT-PCR. Total RNA, isolated from staged embryos and tissues of adults served as template for RT-PCR. PCR products were separated, blotted, and probed with an activin $\beta B$ cDNA probe. Developmental stages (top left) were exposed for 1 day; in adult tissues (top right) $\beta B$ message was detected after 2 hr of exposure. (Bottom) Ethidium bromide staining of the aliquots of the RNA samples added to reverse transcription reactions. and methods), abolished staining, and demonstrated the specificity of $\mathrm{mAb}$ for activin (Fig. 3A,B). Staining in blastulae (Fig. 3D), although weak, appeared uniform.

\section{Activity and generation of dominant-negative variants}

For activity studies, activin $\beta B$ cDNA, as well as its derivatives, was cloned into the expression vector pCMV5 (Andersson et al. 1989). The resulting plasmid, pCßB, was transfected into COS cells or 293 cells. Conditioned medium derived from transfected cells induced elongation of Xenopus animal caps (not shown) as well as the expression of Mix.1 (Rosa 1989) and cardiac actin (Gurdon et al. 1985), [Fig. 5A (lane wt); Fig. 5C (lane wt + con.|l, demonstrating that zebrafish activin is a potent mesoderm inducer.

Activins, like all members of the TGF- $\beta$ superfamily are secreted polypeptides. Preventing the secretion of the preproprotein has led to the generation of dominant-neg-

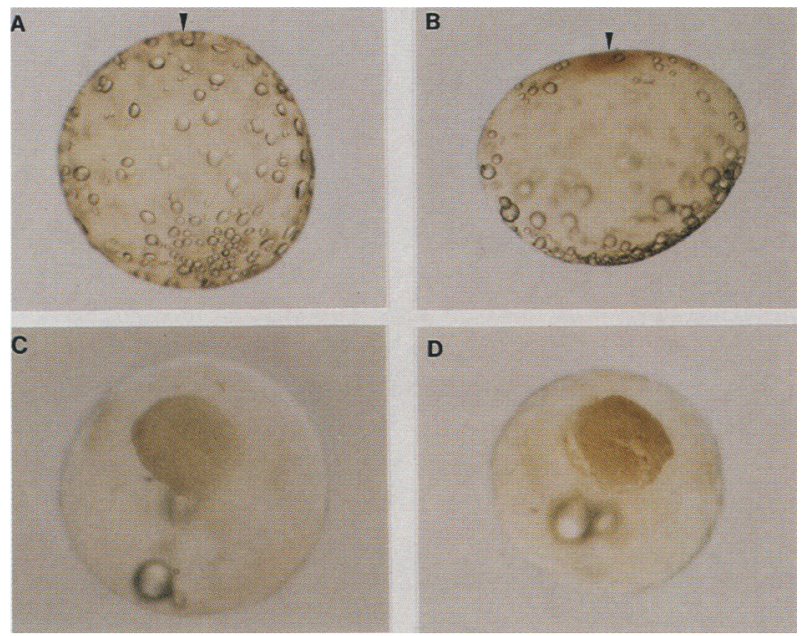

Figure 3. Activin immunoreactivity in the early embryo. Onecell $(A, B)$ and mid-blastula $(C, D)$ embryos were stained by reaction with control serum $(C)$ or with mAb E4 $\langle A, B, D\rangle$, followed by incubation with horseradish peroxidase-coupled secondary antibody and detection with diaminobenzidine. To show the specificity of staining $(A), \mathrm{mAb} \mathrm{E} 4$ was preincubated with an equal volume of supernatant from pC $\beta B$ stably transfected 293 cells. Localization of the single cell is indicated (arrowhead). 
ative variants of TGF- $\beta 1$ (Lopez et al. 1992). The secreted form is active only as disulfide-linked dimer. Activation requires cleavage of the carboxy-terminal peptide from the amino-terminal precursor remainder (for review, see Vale et al. 1990). The active carboxy-terminal dimer is released from the precursor remainder under the correct physiological conditions. It is then thought to interact with a novel type of receptor (for review, see Massagué 19921, a transmembrane protein with serine/threonine kinase (Massagué 1992), or serine/threonine/tyrosine kinase activity (Nakamura et al. 1992).

The structure of the activin molecule itself already offers further potential targets for the creation of dominant-negative variants. TGF- $\beta$ is secreted as an inactive latent complex formed by the association of the aminoterminal precursor remainder and the carboxyl terminus (Roberts and Sporn 1990). By analogy, preventing the cleavage of the activin carboxy-terminal peptide from the amino-terminal part might result in the secretion of nonfunctional activin. In addition, by dimerizing with a wild-type activin molecule, a nonprocessible variant might titrate out wild-type activin. To test this hypothesis, we generated the cleavage sequence (CS) variant by replacing the tribasic cleavage region RKR by HHS (Fig. 4A). This modification should yield an unprocessed inactive protein without leading to a major conformational change.

The second clue for the creation of variants derives from the dimeric nature of the active form. Targets for dominant-negative mutations could be regions in the conserved carboxyl terminus potentially involved in ligand-receptor interaction (Schlunegger and Grütter 1992; Daopin et al. 1992). A change in these regions might either lead to a dominant-negative activity by altering the affinity of the variant/wild-type heterodimer to the receptor or generate an antagonizing form of activin that binds to the receptor without activating it.

To generate a carboxy-terminal point mutation $(\mathrm{Pt}$ variant) we changed the phenylalanine at position 21 of the carboxy-terminal peptide to isoleucine (Fig. 4A). This phenylalanine is conserved throughout the TGF- $\beta$ superfamily (with the exception of Müllerian inhibiting substance, MIS) and is preceding the first $\alpha$-helical domain discussed to be part of the ligand-receptor interaction surface (Schlunegger and Grütter 1992).

Translation in Xenopus oocytes was used to assay the processing and interactions of the wild-type and variant activin. Wild-type activin is secreted and processed by the oocyte to generate a $15-\mathrm{kD}$ peptide (carboxyl terminus) and a $41-\mathrm{kD}$ peptide (precursor remainder) under reducing conditions (Fig. 4B,C; lanes wt red) as described for activin secreted from vaccinina virus-infected tissue culture cells (Huylebroeck et al. 1990). Under nonreducing conditions, the $15-\mathrm{kD}$ species is shifted to $25-\mathrm{kD}$ in agreement with the dimeric structure of activin (Fig. $4 \mathrm{~B}, \mathrm{C})$. A minor additional $\sim 58-\mathrm{kD}$ peptide was also detected under nonreducing conditions. When isolated from the gel and run under reducing conditions, it was

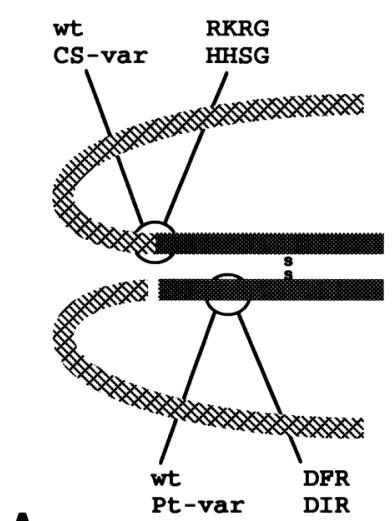

A

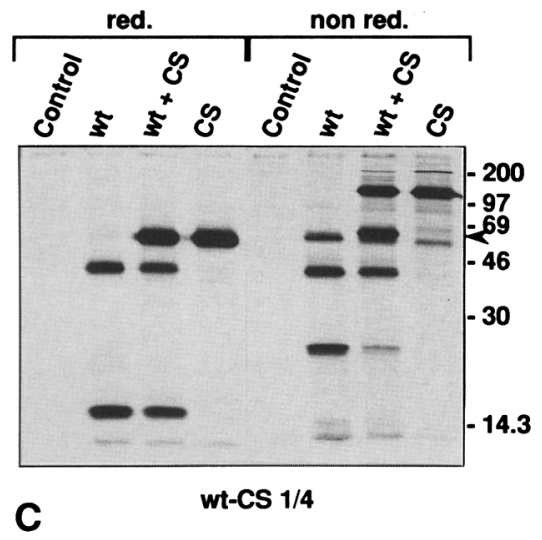

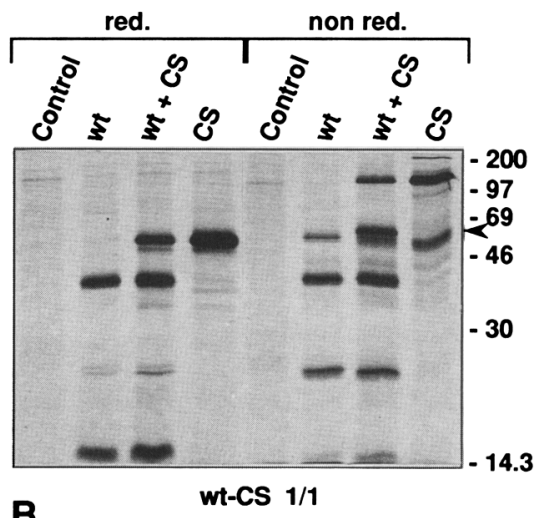

B

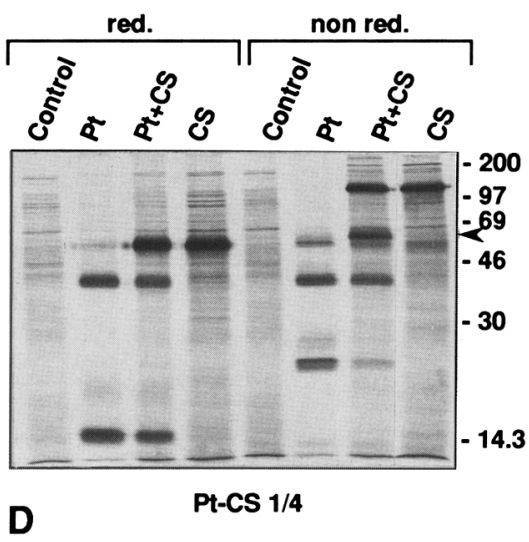

Figure 4. Generation and biochemical characterization of variant activin proteins. $(A)$ Schematic representation of an activin dimer. Precursor remainder is crosshatched; the active carboxy-terminal part is shaded. In the CS variant the wild-type tribasic cleavage site RKR is changed to HHS. In the Pt variant the phenylalanine at position 21 of the mature peptide is changed to isoleucine. $(B-D)$ Proteins secreted from Xenopus oocytes after RNA injection. RNA was transcribed from pSP64T plasmids carrying respectively the wild-type $\mid w t)$, Pt $(\mathrm{Pt})$, or CS $(\mathrm{CS})$ activin cDNA and injected into oocytes. Oocytes were pulse-labeled using $\left[{ }^{35} \mathrm{~S}\right] \mathrm{methionine.}$ Equal amounts of the supernatant were analyzed under reducing (red.) and nonreducing (non red.) conditions on a $12 \%$ SDS-PAGE gel and autoradiographed. $(B, C)$ Interaction between wild-type and CS forms. Note the formation of the additional $65-\mathrm{kD}$ half-processed heterodimer inidicated by the arrowhead (lane $w t+C S$, non red.). Titration of $25-\mathrm{kD}$ species is dose-dependent because it is observed at a wt/CS ratio of $1: 4(C)$ but not at $1: 1(B) .(D)$ Same as in $C$ except that Pt RNA is used instead of wild type. The molecular size markers (in $\mathrm{kD}$ ) are indicated at right. 
split into two peptides of 15 and $41 \mathrm{kD}$, respectively, comigrating with processed peptides of activin $\beta \mathrm{B}$ /data not shown). Most likely, the $58-\mathrm{kD}$ peptide is the result of the formation of an unusual disulfide bridge between the precursor remainder and the carboxy-terminal part of activin $\beta B$, as a result of overexpression in the oocyte. Identical results were obtained with the Pt variant (Fig. $4 \mathrm{D}$. On the contrary, CS protein is secreted as a single species of $58 \mathrm{kD}$ (reducing conditions) and $120 \mathrm{kD}$ (nonreducing), clearly demonstrating that the CS protein can no longer be processed but can still dimerize (Fig. $4 \mathrm{~B}-\mathrm{D})$. Coinjection of RNAs encoding CS and wild-type or $\mathrm{Pt}$ activin $\mathrm{BB}$ leads, under nonreducing conditions, to the simultaneous depletion of the $25-\mathrm{kD}$ band and the accumulation of a new species of $\sim 65 \mathrm{kD}$ (Fig. 4B-D; non red.), a size expected from a heterodimeric CS/wt or $\mathrm{CS} / \mathrm{Pt}$ molecule. When isolated from the gel and run under reducing conditions, the $65-\mathrm{kD}$ species was split into a $15-$ and a $58-\mathrm{kD}$ species, confirming its heterodimeric structure (data not shown). Therefore, although unprocessed, the CS variant can still dimerize with wild-type or Pt forms.

\section{Analysis of the dominant-negative activity in vitro}

Both CS and Pt variants inhibited activin $\beta B$ mesoderm inducing activity when cotransfected with $\mathrm{pC} \beta \mathrm{B}$. Conditioned medium from COS cells cotransfected with pC $\beta B$ and pCMV5 DNAs (ratio 2:1) strongly induces morphogenetic movements (data not shown) and cardiac actin expression (Fig. 5A,B). Replacing pCMV5 with $\mathrm{pC} \beta \mathrm{B}-\mathrm{CS}$ results (at the same ratio) in the strong inhibition of actin expression (Fig. 5A,B) and only minor elongation of the caps. Further increase of the ratio of variant DNA (>50\%) in the cotransfection leads to a supernatant that shows no mesoderm-inducing activity, whereas the corresponding controls significantly induce mesoderm (Fig. 5A,B). Pt variant similarly inhibited wild-type activity, although less efficiently (Fig. 5A,B).

To determine at which level Pt mutant was interfering with activin activity, we mixed media from cells transfected with either wild-type or variant activin plasmids and tested their activity on the induction of caps elongation (not shown) or Mix.1 (Rosa 1989) RNA (Fig. $5 \mathrm{C}, \mathrm{D})$. CS supernatant did not inhibit wild-type supernatant activity (Fig. 5C), supporting the idea that CS and wild-type activin must be cotranslated to interact. On the contrary, $\mathrm{Pt}$ inhibited the elongation of caps /not shown) and Mix.1 induction by activin $\beta B$ (Fig. 5C,D), suggesting that $\mathrm{Pt}$ interferes directly with processed activin either by blocking receptor binding or by blocking the signal transduction pathway. Similar experiments suggested that the $\mathrm{Pt}$ variant is also able to inhibit activin $\beta A$ (data not shown).

The specificity of the interaction of the CS and Pt variants with activin $\beta B$ was tested by analyzing their capacity to interfere with the activity of BMP-4, another potential mesoderm inducer belonging to the TGF- $\beta$ superfamily (Köster et al. 1991) in two different assays. In the first assay, BMP-4 is inducing the differentiation of
SAOS-2 osteogenic sarcoma cell line (Fogh and Trempe 1975 ) cells in vitro, as analyzed by the expression of alkaline phosphatase (Gray et al. 1987). Coexpression in COS cells of the CS or the Pt activin variant with Xenopus BMP-4 did not inhibit noticeably the capacity of Xenopus BMP-4 to induce differentiation of SAOS cells (Fig. 6A, mp). Similarly, adding supernatants from pC $\beta B-P t$ or $\mathrm{pC} \beta \mathrm{B}-\mathrm{CS}$ to supernatants from Xenopus BMP-4-transfected cells did not inhibit the differentiation of SAOS cells induced by BMP-4 (Fig. 6A, ms). In the second assay, BMP-4 RNA injection during the first cell cycle has been shown to ventralize Xenopus embryo mesoderm (Dale et al. 1992; Jones et al. 1992). In particular, animal caps from BMP-4-injected embryos express an increased level of the homeo box gene Xhox3, a marker for posterior mesoderm. If $\mathrm{Pt}$ variant is able to interfere with BMP-4 activity, it should inhibit the increase in Xhox 3 mRNA induced by ectopic expression of BMP-4. To test this, animal caps from control or BMP-4-injected Xenopus blastula were dissected and incubated in dilutions of conditioned media derived from 293 cells expressing either wild-type activin or Pt variant, and corresponding Xhox 3 mRNA levels were measured by RNase protection. BMP-4 injection led to increased levels of Xhox3 mRNA (Fig. 6B). However, incubation of animal caps from BMP-4-injected embryos in Pt-conditioned medium did not markedly inhibit this increase (Fig. 6B; Table 1). In one experiment (involving high concentrations of $\mathrm{Pt}$, levels of Xhox 3 were actually increased by incubation of the caps in Pt-conditioned medium. Such an increase could be interpreted to indicate that activin antagonizes the Xhox3-inducing capacity of BMP-4 and that the Pt variant, by blocking the effect of activin or activin receptor, amplifies or unmasks additional inducing activities of BMP-4. A similar observation was reported in the case of enhanced induction of Xbra by basic FGF (bFGF) in Xenopus embryos injected with truncated XAR1 receptor (Hemmati-Brivanlou and Melton 1992). In summary, both $\mathrm{Pt}$ and CS variants specifically inhibit activin activity by two different mechanisms. CS variant is able to titrate out wild-type activin, whereas Pt variant inhibits the processed protein.

\section{Analysis of the role of activin in vivo}

The involvement of activin in the processes of mesoderm induction and axis formation was addressed directly by injecting $\mathrm{Pt}$ RNA into one of the two blastomeres of the medaka embryo. For each type of injection, several series of experiments were performed. In total, >1500 embryos have been injected with different amounts of the variant RNAs and corresponding controls. The data shown in the figures are representative and have been taken from one series of experiments. Injected embryos were analyzed after $32 \mathrm{hr}$ when controls had completed gastrulation and were at the 12-somite stage.

Embryos injected with high amounts (500 fg) of synthetic Pt RNA (high Pt embryos) exhibited a uniform phenotype. After $32 \mathrm{hr}$ all cells of the embryo were lo- 


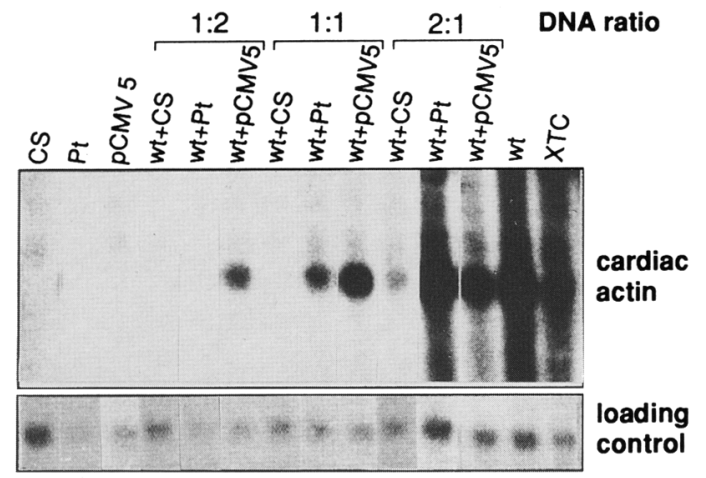

A

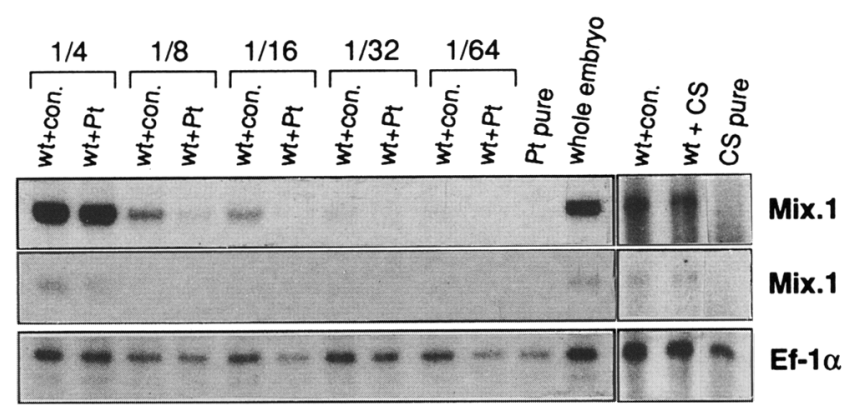

C

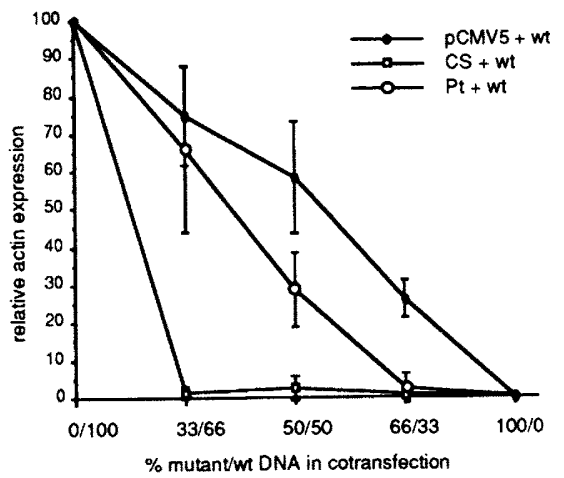

B

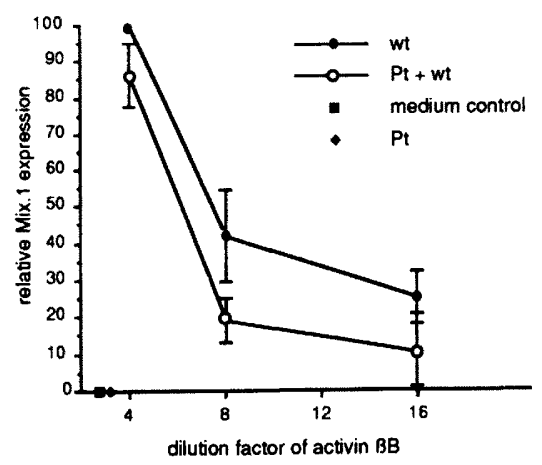

D

Figure 5. In vitro analysis of dominant-negative activity of the variant activin proteins. $|A| \mathrm{CS}$ and $\mathrm{Pt}$ variants inhibit actin induction in Xenopus animal caps when cotransfected with wild-type activin. Stage 8 Xenopus animal caps were incubated with supernatants from cells transfected at the indicated ratio with pCMV5 (control), $\mathrm{pC} \beta \mathrm{B}(\mathrm{wt}), \mathrm{pC} \beta \mathrm{B}-\mathrm{Pt}(\mathrm{Pt}), \mathrm{pC} \beta \mathrm{B}-\mathrm{CS}(\mathrm{CS})$, or a combination of those and incubated until control embryos reached stage 17. RNA was extracted from caps and analyzed by Northern blotting with an $\alpha$-actin probe (top). XTC medium was used as a control for induction (right lane). The autoradiography is shown. As a loading control, the filter was stained with methylene blue, and 18S rRNA staining is displayed (bottom). (B) Quantitation of the effect of the Pt and CS variants shown in $A$. Induction is shown as expression relative to the maximum effect observed when caps were incubated with supernatant from pC $\beta B$-transfected COS cells. The curve represents an average of three different experiments. Error bars are indicated. $(C) \mathrm{Pt}$ activin inhibits the effect of wild-type activin on Mix.1 induction in Xenopus animal caps. RNA was prepared from animal caps incubated in conditioned media from 293 cells transfected with $\mathrm{pC} \beta \mathrm{B}(\mathrm{wt}), \mathrm{pC} \beta \mathrm{B}-\mathrm{Pt}(\mathrm{Pt}), \mathrm{pC} \beta \mathrm{B}-\mathrm{CS}$, or a mixture of the supernatants and incubated until control reached stage 10.5 (early gastrula). In this experiment, $\mathrm{Pt}$ supernatant concentration was kept constant and mixed with varying dilution of supernatant from pC $\beta B$-transfected cells (dilution indicated above). (Con) Control medium. RNA from two caps was hybridized with a Mix.1 RNA probe and a probe for Ef-1 $\alpha$ RNA and processed for RNase protection as described in Materials and methods. (Top and middle) A long (6-day) and a short (16-hr) exposure, respectively, of the same gel (Mix.1). (Bottom) The expression of Ef-l $\alpha$. The relative weakness of the effect observed might come from the lower level of Pt protein present in the medium (data not shown). (D) Quantitation of the effect of $\mathrm{Pt}$ on wild-type activin shown in $C$. Induction was normalized to the amount of Ef-1 $\alpha$ RNA and plotted as expression relative to the maximum effect observed when caps were incubated with supernatant from pC $\beta B$-transfected 293 cells ( $w t+$ con). The curve represents an average of two independent experiments. Induction of Mix.1 obtained at dilution $1 / 32$ and $1 / 64$ is too low to be reproducibly quantitated. Error bars are indicated. The effect of CS variant was studied in independent experiments and not represented on the curve. Quantitation showed that mixture of wild-type and CS activin induced Mix.1 RNA to $98 \%$ of the level induced by wild-type activin alone.

cated at one pole of the yolk sack forming an unstructured "cap." No obvious axis had been formed (Fig. 7A). Time lapse video microscopy revealed that at the time when controls started to gastrulate, cells from the high Pt blastulae did not show any obvious gastrulation movements. Cells were still alive, as methylene blue contained in the medium was efficiently excluded from the embryos. The rate of dead embryos was not signifi- cantly increased (Fig. 10A, below). Histological analysis revealed only two types of cells, a single layer of cells with flat nuclei covering the yolk, presumably the yolk syncytial layer and a multilayer region (the cap) composed of a rather uniform population of cells reminiscent of blastula undifferentiated blastomeres (Fig. 7B). Reduction of the amount of Pt variant RNA injected (100 fg; intermediate $\mathrm{Pt}$ ) led to a shift in the predominant phe- 

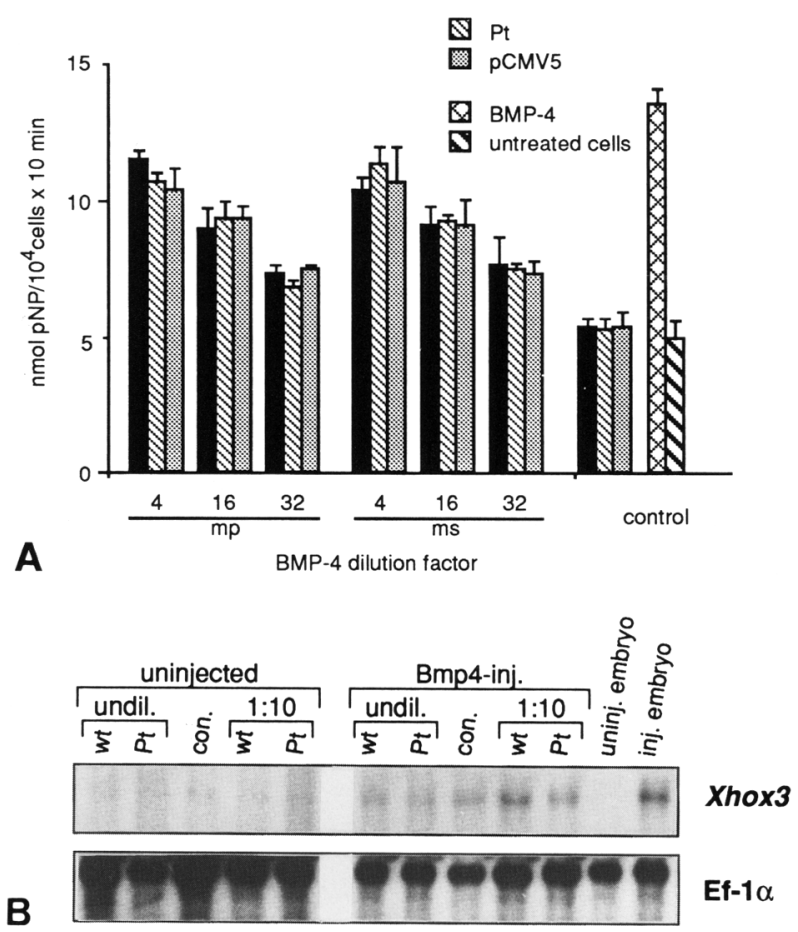

Figure 6. $(A) \mathrm{CS}$ and $\mathrm{Pt}$ activin do not interfere with BMP-4induced differentiation of SAOS cells. SAOS-2 cells were incubated for $36 \mathrm{hr}$ in medium conditioned by COS cells cotrans. fected with constant amount of variant or control DNA /CS, Pt, pCMV5) and indicated dilution of BMP-4 [mixed plasmids (mp)]. Alternatively conditioned media from COS cells transfected with BMP-4 and the activin variants or control (CS, Pt, pCMV5) were mixed and applied to SAOS cells under identical conditions. A constant amount of variant or control and indicated dilution of BMP-4-conditioned medium was used [mixed supernatants (ms)]. Control supernatants (right) were derived from COS cells transfected with respectively pC $\beta B-C S$, pC $\beta B-P t$, pCMV5, or left untreated, respectively. Alkaline phosphatase activity is plotted vs. the plasmid used. $(B)$ Pt treatment does not inhibit Xhox 3 induction in animal caps from BMP-4-injected Xenopus embryos. Stage 8 animal caps were dissected from control or BMP-4 RNA-injected embryos and incubated in medium indicated: (con.) Control; (wt) wild-type activin; $(\mathrm{wt}$ $1: 10)$ same at dilution 1:10, (Pt) Pt variant; (Pt 1:10) same at dilution 1:10. Caps were harvested when sibling embryos reached stage 12 and analyzed for their content of Xhox 3 mRNA by RNase protection.

notype. Most of the embryos (55\% ; Fig. 10A, below) were forming some structures like somites (Fig. 7C, cap with structure, arrowhead). Although no sign of proper axis formation was found in those embryos, mesodermal derivatives such as red blood cells were consistently observed after long-term incubation of the int Pt embryos. $\mathrm{Pt}$ embryos injected with $25 \mathrm{fg}$ of Pt RNA (low Pt) expressed distinct morphological structures. The most prominent phenotype in this group (Fig. 7D) (reduced axis; $48 \%$ of all injected embryos; Fig. 10A) contained an axis with obvious deficiencies in the anterior part such as lack of head or eyes and fore-/midbrain. Interestingly, a minor fraction of the low Pt embryos $(3 \%$, Fig. 10A) exhibited the formation of twin tails. In summary, $\mathrm{Pt}$ RNA injection led to a progressive, dose-dependent loss of axial structures. Strikingly, embryos injected with a given RNA amount exhibited a rather narrow range of phenotypes.

Antibodies specifically recognizing mesodermal structures were used to refine the phenotypical and histological analysis. Notochord, a dorsal mesoderm derivative, was identified with mAb MZ 15 (Zanetti et al. 1985). Staining in the wild-type embryo was first detected at 24 $\mathrm{hr}$ in the posterior notochord, extending from the tailbud to anterior as development proceeds (Fig. 8A,D). Brachyury protein ( $T$ protein), expressed in immediate response to mesoderm induction in frogs (Smith et al. 1991) and fish (Schulte-Merker et al. 1993), was used as a general marker for mesoderm. Its expression pattern in wild-type medaka embryos (Fig. 8B,E) studied with an antiserum, kindly provided by S. Schulte-Merker, is very similar to the expression described for zebrafish (Schulte-Merker et al. 1993).

High Pt embryos did not express detectably MZ 15

Table 1. Effect of activin/Pt variant on Xhox 3 induction by $B M P-4$

\begin{tabular}{llcc}
\hline Injection & Treatment & $\begin{array}{l}\text { Experiment 1 } \\
\text { induction by } \\
\text { BMP-4 }\end{array}$ & $\begin{array}{l}\text { Experiment 2 } \\
\text { induction by } \\
\text { BMP-4 }\end{array}$ \\
\hline $\begin{array}{l}\text { Control } \\
\text { BMP-4 sense }\end{array}$ & $\begin{array}{l}\text { control } \\
\text { control } \\
\text { BMP-4 sense } \\
\text { wild-type } \\
\text { activin }\end{array}$ & 1.00 & 1.00 \\
BMP-4 sense & $\begin{array}{c}\text { wild-type } \\
\text { activin } 1 / 10\end{array}$ & 3.83 & 2.73 \\
BMP-4 sense & $\begin{array}{l}\text { Pt variant } \\
\text { BMP-4 sense }\end{array}$ & 2.94 & 1.51 \\
\hline
\end{tabular}

The gels from Fig. 6 (experiment 1, wild-type $\approx 10 \mathrm{U} / \mathrm{ml}$ ) and from another experiment carried out with 10 -fold concentrated supernatants (experiment 2) were quantitated using a Molecular Dynamics Phospholmager device. Treatment indicated in column 2 is described in Fig. 6. RNA amounts were normalized with regard to Ef- $1 \alpha$ levels. Relative induction levels $(R)$ shown in the two right columns were calculated according to the formula

$$
R=\frac{\begin{array}{c}
\text { Amount of } X h o x 3 \text { mRNA in } \\
\text { treated caps from injected embryos }
\end{array}}{\text { Amount of Xhox3 mRNA in }}
$$

In experiment $1, \mathrm{Pt}$ supernatant inhibits slightly $X$ hox 3 induction, but this effect was not observed with a more concentrated supernatant (experiment 2; Fig. 6, cf. lanes 5 and 6 with lane 2). In experiment 2, wild-type activin clearly inhibits Xho3 induction. This supernatant has a 10 -fold higher inducing activity than the one used by Dale et al. (1992) and might override BMP-4 effect. In this sample, animal caps exhibited strong pseudogastrulation movements typical for activin-mediated mesoderm induction. 


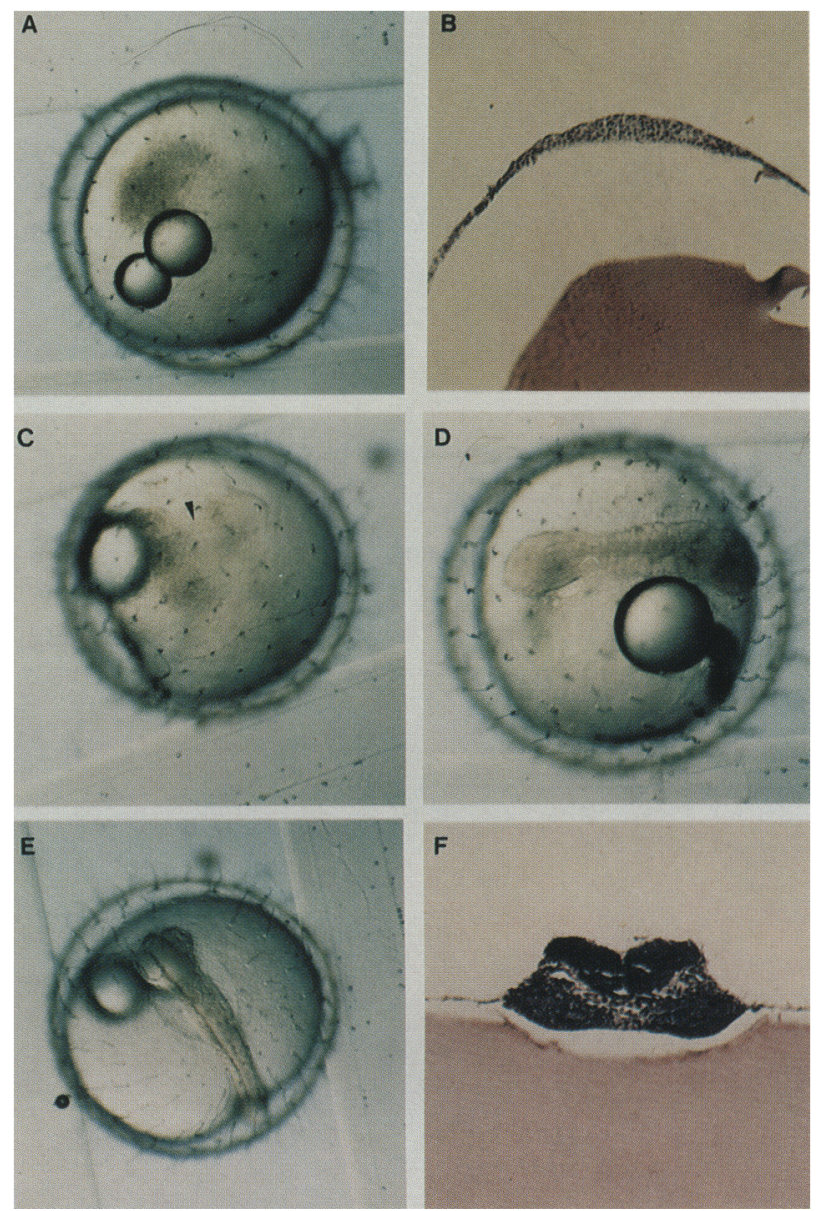

Figure 7. Pt RNA injection disrupts axis formation in medaka. Medaka embryos were injected at the two-cell stage into one of the blastomeres with different amounts of Pt RNA and kept at $28^{\circ} \mathrm{C}$ for $32 \mathrm{hr}$. (A) Caps are obtained after injection of $500 \mathrm{fg}$ of Pt RNA. $(B)$ The caps shown in $A$ exhibit a blastula-like histology. $(C)$ Injection of intermediate amounts of Pt RNA (100 fg) predominantly leads to the cap with structure phenotype, show here with a somite-like structure (arrowhead). $(D)$ Low amounts of Pt RNA ( $25 \mathrm{fg}$ ) induce loss of anterior structures. $(E)$ Control uninjected embryo. $(F)$ Cross section through the trunk region of a control embryo. Diameter of the embryos is $\sim 1 \mathrm{~mm}$.

antigen or $\mathrm{T}$ protein (Fig. $8 \mathrm{G}, \mathrm{H}$ ). In caps with structure MZ 15 and T-protein antibodies labeled cells appearing in a connected cord. In contrast to normal embryos this staining was detected almost exclusively on the surface of the embryo rather than inside (Fig. 8J,L), suggesting that some mesoderm had differentiated without being able to gastrulate inside the embryo.

Some of the 32-hr intermediate Pt embryos looked like retarded gastrula $(50 \%$ epiboly; Fig. $8 \mathrm{~K})$. However, none of them expressed the $\mathrm{T}$ protein as a complete ring as usually seen in wild-type $50 \%$ epiboly gastrula (Fig. 8 B). Low Pt embryos with reduced axis in most cases showed T-protein expression anterior to the truncation of the axis (Fig. 8O), suggesting that the anterior part of the embryo had acquired a posterior character as a result of Pt expression.

We conclude from these experiments that Pt RNA injection efficiently inhibits mesoderm induction in the medaka embryo and that activin is necessary for both mesoderm induction and axis formation in fish medaka.

Recent experiments suggested that in Xenopus, activin signaling inhibits the spontaneous conversion of ectoderm to neuroectoderm (Hemmati-Brivanlou and Melton 1992). In particular, animal caps from Xenopus embryos expressing high amounts of XAR1-truncated activin receptor express large amounts of neural cell adhesion molecule (N-CAM), a marker for early neural tissue. We investigated whether this result could be generalized to lower vertebrates. A monoclonal antibody (mAb D3; Schlosshauer 1989) cross-reacting with goldfish N-CAM (Bastmeyer et al. 1990), was used to identify neural tissue in injected embryos. In wild-type embryos, D3 detected $\mathrm{N}$-CAM expression on the surface of neural tissue cells. It first appears at the neurula stage in the neural keel. In older embryos the entire central nervous system is stained (Fig. 8C,F). Animal caps were dissected from control of high Pt medaka embryos and stained with mAb D3. Because medaka gastrula fate map is ill defined, we relied on zebrafish gastrula fate map (Kimmel et al. 1990). Animal caps from control embryos did not exhibit obvious N-CAM expression (Fig. 9, cf. A and B). On the contrary, animal caps from high $\mathrm{Pt}$ embryos exhibited strong staining with $\mathrm{mAb}$ D3, suggesting that Pt ectopic expression led to elevated expression of N-CAM and neural tissue formation (Fig. 9F). Surprisingly however, only $55 \%$ of high Pt embryos did express N-CAM. However, this expression was restricted to small patches of cells (Fig. 8I). In intermediate Pt embryos, expression of $\mathrm{N}$-CAM in cells organized in a tissue-like manner was clearly observed (Fig. 8M). Low Pt embryos with reduced axis showed abundant expression of N-CAM (Fig. 8P). In conclusion, although we observed enhanced expression of N-CAM in animal caps from medaka embryos injected with Pt RNA, injection of high amounts of $\mathrm{Pt}$ RNA did not result in the formation of large amounts of neural tissue in whole embryos, as would have been expected.

\section{Maternal vs. zygotic contribution}

In the early embryo, activin is found as a maternal protein (Asashima et al. 1991; Ge et al. 1993a; J. Wittbrodt and F. Rosa, this paper), whereas activin $\beta B$ is transcribed zygotically (late blastula stage; J. Wittbrodt and F. Rosa, this paper). Both forms could be involved in mesoderm induction and axis formation. To analyze the role of $z y-$ gotically expressed activin in vivo we used the property of the CS variant to titrate out activin upon cotranslation. CS variant mRNA was injected into each blastomere of the two-cell embryo. Stability of CS mRNA was tested by Northern blot analysis (Table 2). At a time at which the zygotic transcript of activin is first detected in the embryo (10-12 $\mathrm{hr}$ after injection), there is still 80 
Figure 8. Pt RNA injection alters mesoderm and the expression of neural markers in medaka embryos. Embryos injected with varying amount of Pt RNA $\{G-P$; amount injected indicated at right) or left uninjected $(A-F)$ were collected after $32 \mathrm{hr}$ (injected embryos and control embryos in $D, E, F)$ at $28^{\circ} \mathrm{C}$ or after $24 \mathrm{hr}(A), 16 \mathrm{hr}(B)$, $18 \mathrm{hr}(C)$, fixed and processed for wholemount immunostaining with antibodies (indicated at top). $(G, H, I)$ Cap embryos do not express MZ15 antigen or T protein but express $(55 \%)$ a low level of N-CAM in a small patch of cells (arrowhead). $(J, K, L, M)$ Cap with structure embryos express the three markers in a disorganized fashion. Note that in $J$ and $L$, marker is expressed at the surface of the embryo (arrow in $L$ ). Occasionally, we observed a structure reminiscent of an early neural keel larrowhead in $L) .(N, O, P)$ Reduced axis embryos. Note the anterior staining in $O$ for $\mathrm{T}$ protein. $\mathrm{N}$-CAM seems expressed more strongly in $P$ than in wild-type embryos $($ cf. $F)$. Dorsal view, anterior to the left $(A, C, D, L, M, P)$; lateral view, anterior to the left $(E, f, N)$; anterior view $|O|$.

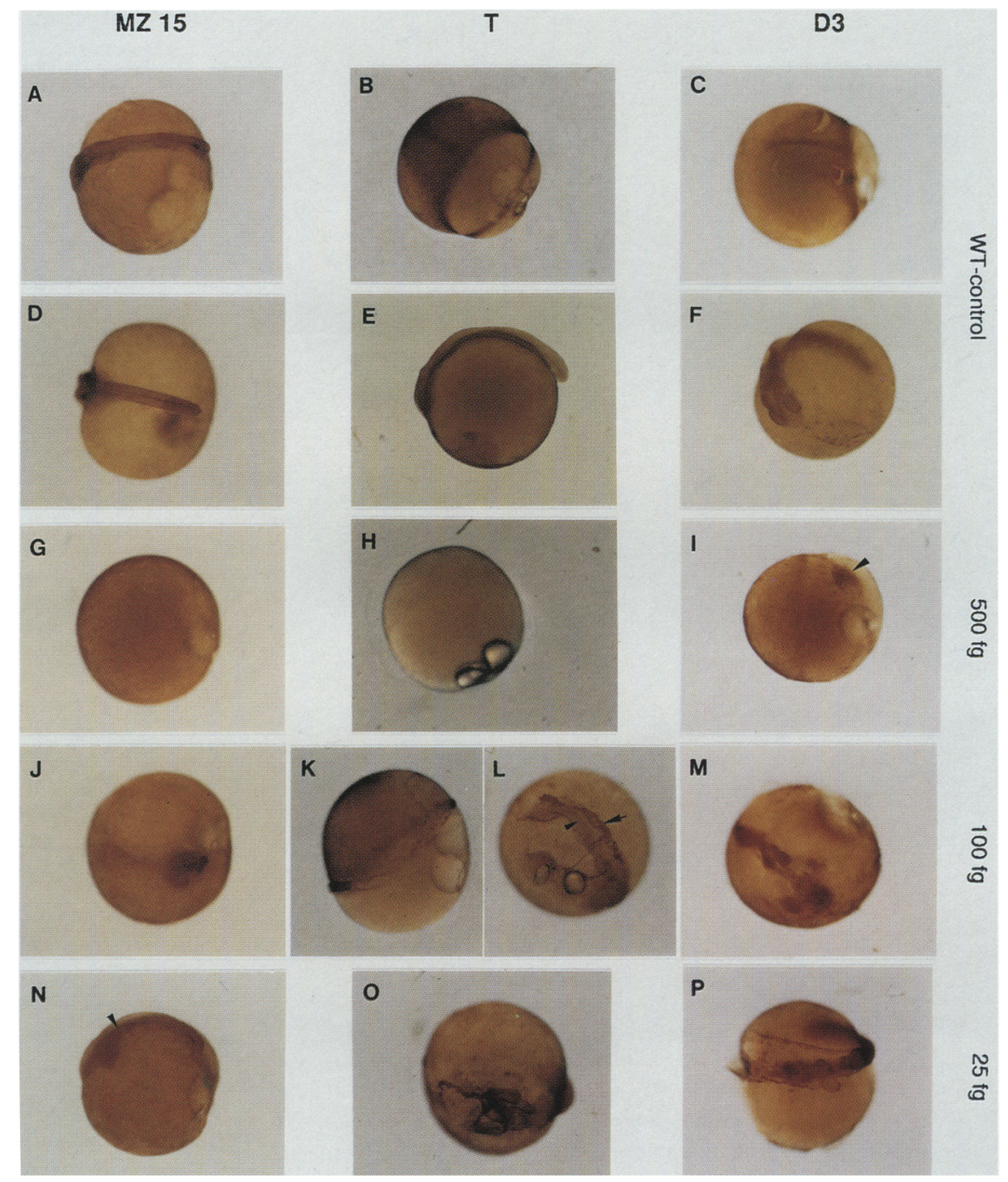

pg of CS RNA present in the blastula. This corresponds to at least a 100- to 1000-fold molar excess over the activin mRNA transcribed in the embryo, as we cannot detect the endogenous mRNA by Northern hybridization in embryos. The phenotype of the CS embryos is indistinguishable from control injected or uninjected sibling embryos throughout their entire development (Fig. 10B).

To demonstrate that the CS variant has the potential to titrate out activin in vivo, we coinjected it with wildtype activin mRNA. Zebrafish activin $\beta B$, as well as mouse $\beta A$ RNA injection, leads to multiple axis formation at a high frequency $154 \%$ and $54 \%$, respectively; Fig. $10 \mathrm{~B} \mid$. In both cases, this effect is blocked by the coinjection of a 20- to 40-fold excess of the CS variant RNA /Fig. 10B).

Therefore, the activin involved in mesoderm induction and axis formation in medaka does not need to be translated prior to its use. A logical conclusion is that the activin involved is stored in the egg as a maternal protein.

\section{Rescue of the effect of Pt}

If the defects in axis formation and mesoderm induction observed in the Pt embryos are caused by the Pt variant protein, coinjection of an excess of wild-type RNA should rescue normal embryonic development. Coinjection of $2.5 \mathrm{pg}$ of wild-type activin RNA and $500 \mathrm{fg}$ of Pt RNA led to embryos exhibiting stronger epiboly movements (Fig. 10C,D). Coinjected embryos $(n=61)$ reproducibly resumed $T$ expression at the rim of the blastoderm as well, although immunostaining was weaker than $T$ expression in the germ ring of wild-type embryos. However, small clusters of cells, isolated from the blastoderm and localized to the vegetal pole, exhibited strong staining. Coinjection did not lead to recognizable phenotypes in late embryos (data not shown), although some embryos with multiple axes were obtained $n=4$ of 61-no embryo with multiple axes was found among high Pt embyos|. There is one major caveat in this approach: Injecting activin RNA at the two-cell stage makes it likely that all cells of the embryo will be in 


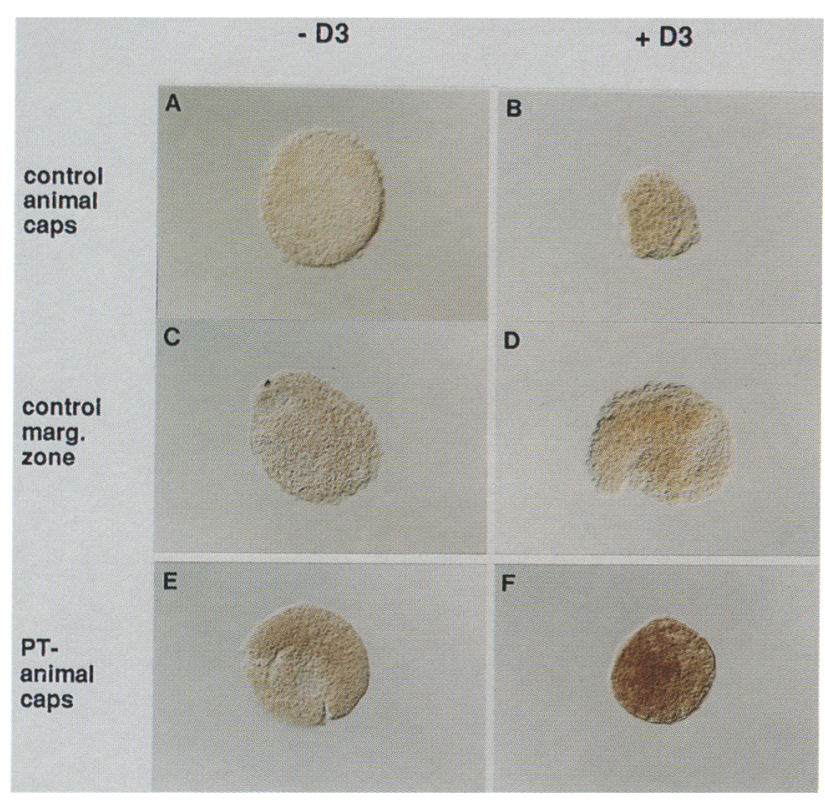

Figure 9. N-CAM expression is induced in animal caps isolated from $\mathrm{Pt}$-injected medaka embryos. The animal cap region (or the marginal zone) from early blastula (stage 10) embryos was dissected and incubated in isolation until sibling embryos reached the 12-somite stage. Explants were then processed for immunohistochemistry with (+D3) or without (-D3) mAb D3. Two independent experiments involved a total of 10 explants $(A), 30(B), 30(C), 25(D), 10(E)$, and $30(F)$ explants.

contact with wild-type activin. Therefore, unlike the experiments involving the use of a dominant-negative form of the activin receptor (Hemmati-Brivanlou and Melton 1992), we expect that all of the competent cells will be in contact with wild-type activin, resulting in nonorganized mesoderm (Cooke et al. 1987). On the other hand, a specific block of Pt should specifically rescue its phenotype. Although CS injection does not affect development, it can titrate out activin activity upon coexpression (Fig. 5A,B). By the same mechanism as demonstrated above (Fig. 4D), it should be able to block Pt activity in embryos. We used this property to test the specificity of the Pt effect on developing fish embryos. Pt and increasing amounts of CS mRNA were coinjected. The CS RNA rescues the effect of the Pt RNA as assayed

Table 2. Stability of CS-RNA after injection

\begin{tabular}{lrrrrrrrr}
\hline $\begin{array}{l}\text { Hours after } \\
\text { injection }\end{array}$ & 0 & 2 & 6 & 8 & 10 & 22 & 26 & 32 \\
$\begin{array}{l}\text { Intact CS-RNA } \\
\text { (pg) }\end{array}$ & 120 & 93 & 91 & 86 & 84 & 57 & 54 & 25 \\
\hline
\end{tabular}

RNA was injected into both blastomeres of the two-cell embryo and embryos were allowed to develop. After the given time, RNA from five embryos for each time point was isolated. On Northern blots the amount of intact CS-RNA was quantitated in comparison to loaded controls. Onset of endogenous medaka activin $\beta B$ expression is after $10 \mathrm{hr}$. by the phenotype analysis. Analogous to the experiments described above, the phenotype observed depends on the dose of remaining Pt activity. At a 10 -fold molar excess of CS over Pt $(250 \mathrm{fg} / 25 \mathrm{fg})$ the number of normal embryos was increased from $12 \%$ to $33 \%$. At the same time, the number of embryos with reduced axes were significantly decreased (from $48 \%$ to $21 \%$ ) (Fig. 10E). An almost complete rescue ( $78 \%$ normal embryos) was obtained at a 20 -fold molar excess of the CS RNA over Pt RNA.

\section{Discussion}

Partial sequences of the genes encoding activin $\beta B$ and $\beta A$ have been cloned by PCR from medaka and zebrafish genomic DNA. This confirms the presence of activin genes in fish, as initially reported in goldfish by $\mathrm{Ge}$ et al. (1993b). Activin $\beta B$ was cloned as a full-length cDNA. $\beta B$ mRNA is expressed both in the adult ovary and during embryogenesis at approximately the time of midblastula transition. With a monoclonal antibody to human activin, we show here that activin reactivity is present as a maternal component in the egg and persists until at least the blastula stage.

To elucidate the role of maternal and zygotic activin in mesoderm induction and axis formation in vivo, we have designed variant forms of the protein. Our experiments have demonstrated that the two types of variants specifically inhibit wild-type activin activity on explanted $X e$ nopus animal cap cells by two different mechanisms. The CS variant inhibits activity only when coexpressed in the same cells with wild-type activin. Coexpression results in the formation of secreted heterodimers that cannot be processed and leads to the depletion of the wild-type activin pool. This type of dominant-negative mutation that is specific for activins and does not interfere with BMP-4 might be of general use throughout the TGF- $\beta$ gene family. In transgenic animals a targeted expression and dominant-negative interaction with given TGF- $\beta$ family members may permit the correlation of temporal expression patterns and the function of the factors analyzed.

The same is true for the Pt variant. In contrast to CS, the $P t$ variant behaves as an inhibitor of activin $\mid \beta A$ and $\beta B /$ protein. This may be attributable to Pt protein binding to the activin receptor without activating the signal transduction cascade. It could also be attributable to interaction with related receptors, with the wild-type activin itself, or with downstream components of the activin signaling pathway. The Pt variant shows high specificity in the interactions with activins and does not interfere with signaling pathways of distantly related members of the TGF- $\beta$ family like BMP-4. This leads us to favor the hypothesis that the $\mathrm{Pt}$ activin $\mathrm{B}$ is binding to an activin receptor without activating the signal transduction cascade. Therefore, we would postulate that different domains of the mature activin protein are required for binding to and activation of the receptor. Throughout the TGF- $\beta$ superfamily the phenylalanine residue changed to isoleucine in the Pt variant is highly con- 

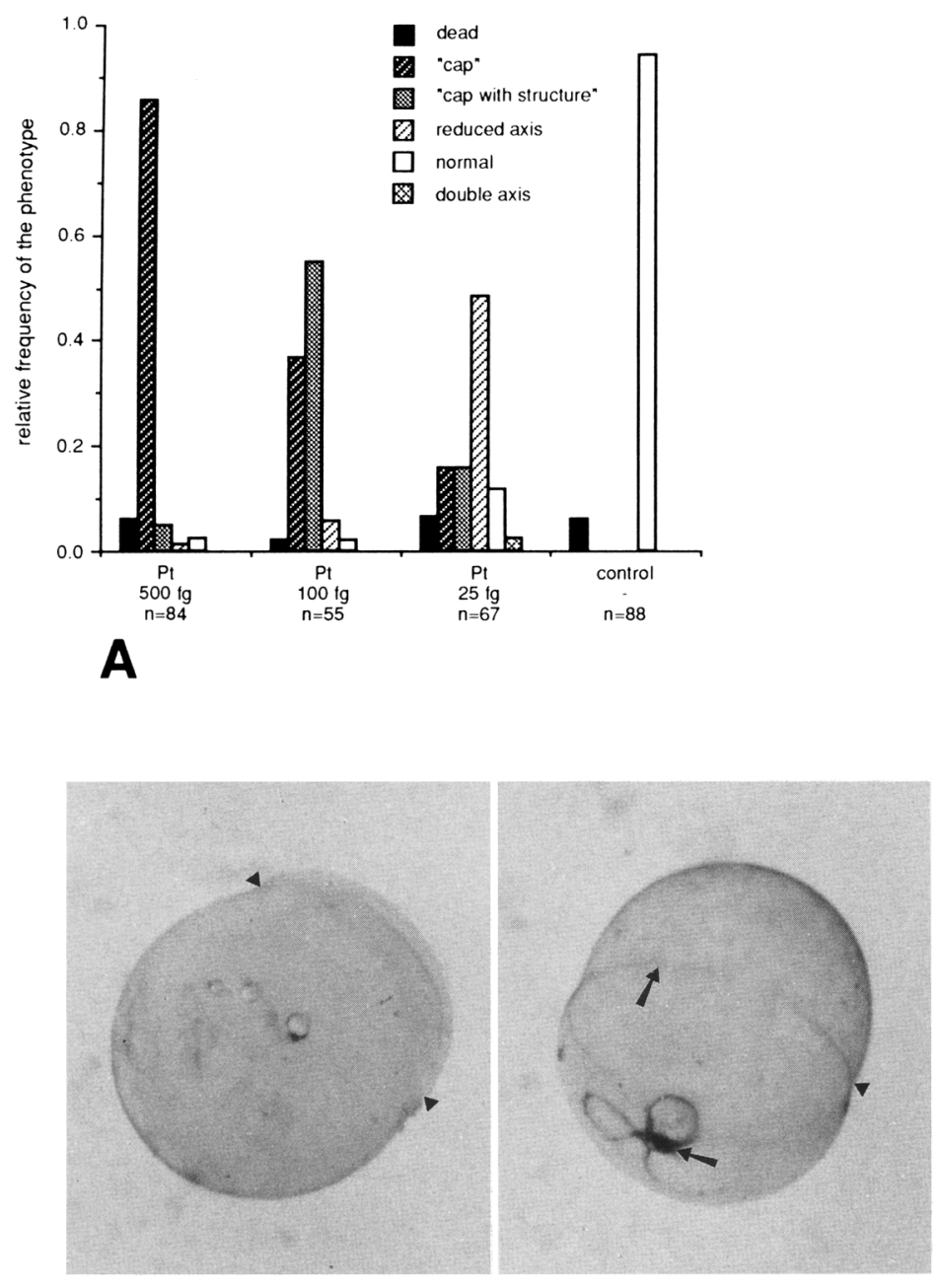

C
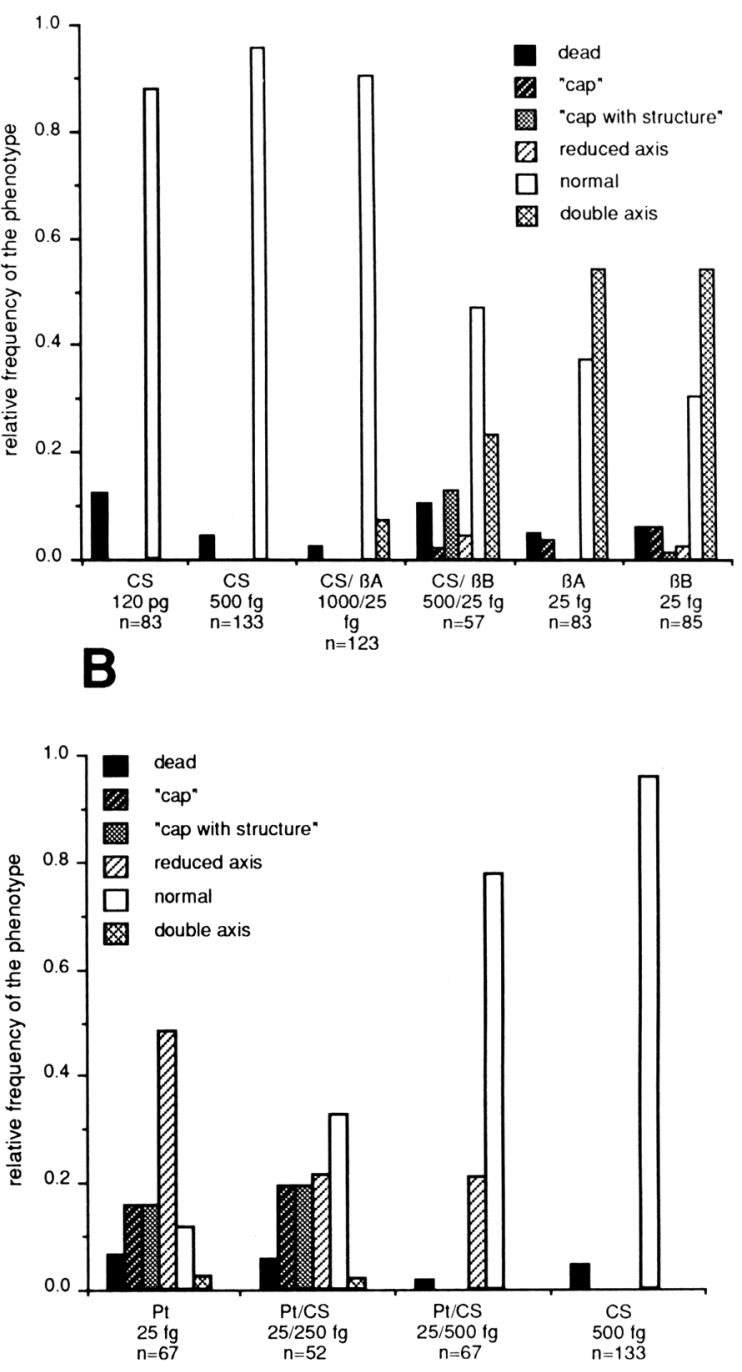

E

Figure 10. Quantitation and specificity of Pt effect. Embryos were injected with RNA encoding mouse activin $\beta A$ ( $\beta A$ ), zebrafish activin $\beta B(\beta B)$, or variants $(\mathrm{Pt}, \mathrm{CS})$ and analyzed after $32 \mathrm{hr}$. Relative frequency of the phenotypes observed was plotted against the amount and type of RNA injected. $|A|$ Pt induces dose-dependent loss of axis. $|B| C S$ variant suppresses the effect of wild-type activins on medaka embryos. $(C, D)$ Coinjection of wild-type activin rescues $T$-protein expression in high Pt embryos. Embryos $(\sim 30$ each) were injected with high amount of $\mathrm{Pt}(C)$ or $\mathrm{Pt}$ and a fivefold excess of activin $\beta B$, respectively $(D)$. After $32 \mathrm{hr}$, expression of Brachyury protein was analyzed as described in Fig. 8. Note that epiboly proceeds to $70-90 \%$ in coinjected embryos $(D$, arrowhead $)$ in comparison to high Pt embryo where only $30 \%$ epiboly is reached $(C$, arrowhead). Brachyury protein is detected at the level of the germ ring and in cells surrounding the oil droplets (arrows) in coinjected embryos $(D)$, whereas no staining can be detected in the high Pt embryo $|C|$. Further increase in wild-type RNA injection prevented the resumption of epiboly $(E)$. CS variant suppresses the effect of Pt variant on medaka embryos. The data in the graphs are representative of three independent experiments.

served, with one exception. The only exception, MIS, inhibiting the formation of the Müllerian duct, contains a leucine residue at this same position. This region of the factor could itself be involved in the activation of the receptor or it could be required for the coupling of binding and activation functions. The first finger domain following the modified residue is thought to be involved in ligand-receptor interaction (Schlunegger and Grütter 1992). It may be required for specific binding of each ligand to its corresponding receptor, whereas another "activation domain" is used universally. More detailed analysis of the variant-receptor interactions will help to clarify this point.

We have used CS and Pt variants to probe the role of activin during early embryogenesis. The injection of $\mathrm{Pt}$ RNA prevents mesoderm and axis formation in a dosedependent manner. Taken together, our results argue strongly for the involvement of activin in those processes. Two control experiments make it unlikely that the effects observed are artifacts. First, the injection even 
of highest amounts (120 pg) of the inactive CS variant does not obviously affect the embryonic development. Second, the effect of the Pt variant can be rescued by titrating it out with the CS variant. Different amounts of the Pt variant lead to the development of embryos with quite distinct phenotypes. The formation of caps peaks at highest Pt concentrations. The cap with structure is predominantly found at intermediate Pt concentrations but not or to a much lower extent at higher or lower concentrations. Embryos with reduced axial structures are most abundant after injection of the lowest amounts of Pt. The observation of graded effects after injection of the $\mathrm{Pt}$ variant is in good agreement with the idea of an activin activity gradient (Green et al. 1992). However, we find no evidence of asymmetric repartition of activin in the fish embryo by immunostaining. Because the Pt variant does not enable us to distinguish between activin $B$ and activin $A$, it is possible that one form of activin $(\mathrm{A}$, $B$, or $A B \mid$ is present maternally and in a graded fashion. Alternatively, activin might be uniformly distributed but asymmetrically activated. Further experiments are needed to answer these questions.

It has been suggested that in Xenopus the zygotically transcribed activin $\beta B$ might be involved in mesoderm induction (Thomsen et al. 1990). On the other hand, we and others find evidence for the presence of maternal activin in frogs (Asashima et al. 1991) and fish (Ge et al. 1993a; J. Wittbrodt and F. Rosa, this paper). CS RNA injection, even in excess does not perturb medaka development. Therefore, translation (and zygotic expression) of activin $\beta B$ or $\beta A$ is not required for mesoderm induction and axis formation in fish. Comparison of the effects of $\mathrm{Pt}$ and CS RNA clearly demonstrates that only maternal activin can be involved in these processes. Other factors have been implicated in those processes, including $\mathrm{Vgl}$ and BMP-4, which are also present maternally (Weeks and Melton 1987; Köster et al. 1991; Dale et al. 1992; Jones et al. 1992). It will be interesting to use a similar approach to understand the respective involvement of those TGF- $\beta$-related molecules.

Inhibition of activin signaling in Xenopus has been postulated as a prerequisite for neural induction in $\mathrm{Xe}$ nopus (Hemmati-Brivanlou and Melton 1992). High Pt injections led to high N-CAM levels in prospective ectoderm of medaka embryos. Our results are therefore in agreement with the enhanced N-CAM expression in animal caps from Xenopus embryos injected with XAR1truncated activin receptor. However, in our hands, about half of high Pt embryos express no detectable N-CAM levels. Clearly, animal cap cells from Pt-injected embryos behave differently, depending whether they are maintained in the whole embryo environment or dissected away and cultured in isolation. One possible explanation is that animal caps cells from Pt-injected embryos receive additional signals that prevent them from becoming neuroectoderm. Alternatively, blocking activin activity might just reinforce a natural predisposition of ectoderm to become neuralized as established previously in Urodeles (Holtfreter 1948). Further experiments are needed to clarify this point.
In terms of evolution, the mechanism for the formation of mesoderm and the body axis utilized by lower vertebrates as well as the factors involved in this process appear to be highly conserved. The dominant-negative variants of activin introduced in this paper might provide the tools to address these questions and should be useful to elucidate the role of other members of the TGF- $\beta$ family in vivo.

\section{Materials and methods}

\section{PCR amplification and cloning of PCR products}

We used modified degenerate oligonucleotides described previously (Thomsen et al. 1990). The amino-terminal primer is $5^{\prime}$ GGI (CT)TI GA(AG) TG(CT) GA(CT) GG-3'; the carboxy-terminal primer is $5^{\prime}$-ICC (AG)CA /CT)TC (CT)TC IAC IAT-3'. PCR amplification was performed on $10 \mathrm{ng}$ of medaka and zebrafish genomic DNA. The 50- $\mu$ l reactions consisted of $1 \times$ buffer, $0.2 \mathrm{~mm}$ each of dNTP, $4 \mu \mathrm{M}$ each primer, and 2 units of Taq DNA polymerase (Cetus). Reactions were cycled 35 times (1 min each at $92^{\circ} \mathrm{C}, 43^{\circ} \mathrm{C}$, and $72^{\circ} \mathrm{C}$ ) in a Peltier driven thermocycler (Wittbrodt and Erhardt 1989). The annealing temperature was increased through cycles $1-4$ from $37^{\circ} \mathrm{C}$ to $43^{\circ} \mathrm{C}$. After amplification, the reactions were run on a $3+1 \%$ NuSieve/ agarose gel in $1 \times$ TAE. The 350 -bp product was cloned into the PCR-1000 vector (Invitrogen).

\section{Cloning of full-length activin $\beta B c D N A$, expression in mammalian cells, and assays}

The zebrafish activin $\beta B$ clone was isolated from a cDNA library established from 20 - to 28 -hr-old zebrafish embryos and kindly provided by $\mathrm{R}$. Riggleman and $\mathrm{K}$. Helde /University of Utah, Salt Lake City) with the medaka activin $\beta B$ probe. A 3.02 -kb cDNA was sequenced in both directions following exonuclease III-nested deletions using the Sequenase kit (U.S. Biochemical). The complete sequence has been submitted to the EMBL data base (accession no. X76051). A 1260-bp BspHI-NsiI fragment containing the entire coding region was subcloned into the EcoRI and PstI sites of the pCMV5 vector (Andersson et al. 1989) to generate the plasmids $\mathrm{pC} \beta \mathrm{B}$ (wild type), pC $\beta B-C S$ (CS variant) and $\mathrm{pC} \beta \mathrm{B}-\mathrm{Pt}$ ( $\mathrm{Pt}$ variant). COS cells were transfected by the DEAE-dextran method (Sambrook et al. 1989). 293 Cells were stably transfected with activin-pCMV constructs and a plasmid carrying neomycin resistance (pNEOßGal, Stratagene) under G418 selection as described (Chen and Okayama 1987). Serum-free DMEM medium was conditioned for $60 \mathrm{hr}$ and then assayed on stage 8 Xenopus animal caps at a 1:4 dilution in 1× MMR (Gurdon et al. 1985; Smith 1987). SAOS cells treated with the appropriate supernatant for 2 days were processed for alkaline phosphatase in quadruplicates as described (Gray et al. 1987).

\section{Site-directed mutagenesis, plasmid constructs, and in vitro transcriptions}

Site-directed mutagenesis was performed on activin $\beta B$ cDNA in pBluescript using the oligonucleotides 5 '-CGC ATC CAT CAT TCA GGC TTG GAG-3' (CS-variant) and 5'-TCG ACA TCC GGC TCA T-3' (Pt-variant) according to Kunkel (1985). A 1260-bp BspHI-Nsil fragment (see above) was ligated into the BgIII-linearized pSP64T (Krieg and Melton 1984). Mouse ovary activin $\beta A$ cDNA was obtained by RT-PCR and subcloned into pSP64T. Capped RNA was prepared as described after linearization of the plasmids with Xbal (Krieg and Melton 1984). 
RNA injection into two-cell embryos

About $25 \mathrm{fg}$ to $60 \mathrm{pg}$ of mRNA was injected into one or two blastomeres at the two-cell stage. For injections, embryos were kept in $1 \times$ Yamamoto ringer (Yamamoto 1975 ) at $18^{\circ} \mathrm{C}$, fixed in an agar well. RNA was diluted in $1 \times$ Yamamoto ringer containing $0.1 \%$ phenol red and $20 \mathrm{ng} / \mu \mathrm{l}$ of stage 15 poly $(\mathrm{A})^{-}$RNA. Injections were performed using glass capillary needles $\langle 3-5 \mu \mathrm{m}$ in diam.). Injected embryos were transferred to a $27^{\circ} \mathrm{C}$ incubator. After $12 \mathrm{hr}$, the medium was changed to embryo-rearing medium containing $1 \% \mathrm{NaCl}, 0.03 \% \mathrm{KCl}, 0.04 \% \mathrm{CaCl}_{2}, 0.16 \%$ $\mathrm{MgSO}_{4}$, and $0.0001 \%$ methylene blue.

Injections of capped BMP-4 RNA into two-cell Xenopus embryos and measurement of Xhox 3 levels were performed exactly as described (Dale et al. 1992).

\section{Oocyte injections and analysis of secreted proteins}

Xenopus oocytes were prepared and injected with 10-30 ng of RNA as described (Krieg and Melton 1984). Injected oocytes (10) were pulse-labeled in $50 \mu \mathrm{l}$ of OR2 medium with $30 \mu \mathrm{Ci}$ of $\left[{ }^{35} \mathrm{~S}\right]$ methionine for $2 \mathrm{hr}$. Oocytes were incubated further in fresh OR2 overnight. Supernatants were analyzed on $12 \%$ SDSPAGE and processed for autoradiography.

\section{RNA analysis}

Total RNA was extracted as described (Sargent et al. 1986) and analyzed on Northern blots or by RNase protection using standard procedures (Sambrook et al. 1989). Gels were analyzed and quantitated using a Molecular Dynamics PhosphorImager. Autoradiographs were scanned and quantitated using the Molecular Dynamics image analysis system.

\section{Isolation and $R T-P C R$ analysis of RNA}

Total RNA (500 ng) was DNase treated, phenol extracted, precipitated, and reverse transcribed using an oligo/dT/ primer and 200 units of Moloney murine leukemia virus reverse transcriptase (GIBCO-BRL). Resulting cDNAs were amplified by PCR with 5' primer 5'-CGA CAC GGG GGC TTA-3' and $3^{\prime}$ primer 5'-GTA GTA CAG CAT GGA CA-3' specific for medaka activin $\beta B$. The $50-\mu l$ reactions consisted of $1 \times$ buffer, $0.2 \mathrm{~mm}$ each of dNTP, $1 \mu \mathrm{M}$ each primer, and 0.1 unit of Taq DNA polymerase (P.H. Stehelin, Basel). The reactions were cycled 25 times $\left(92^{\circ} \mathrm{C}\right.$ for $1 \mathrm{~min} ; 52^{\circ} \mathrm{C}$ for $1 \mathrm{~min}, 72^{\circ} \mathrm{C}$ for $\left.1 \mathrm{~min}\right)$, including a hot start.

\section{Antibodies and immunohistochemistry}

The mAb MZ 15 (Zanetti et al. 1985) was used at a dilution of $10^{-3}$. T-protein antiserum (Schulte-Merker et al. 1993) was diluted to $0.2 \times 10^{-4}$. Medaka N-CAM was stained with mAb D-3 (Schlosshauer 1989; Bastmeyer et al. 1990) at a dilution of $10^{-4}$. The mAb E4 against human activin was obtained from Nigel Groome (NIMR, London, UK) and used at a dilution of $10^{-3}$. Embryos were fixed for $>6 \mathrm{hr}$ with $4 \%$ paraformaldehyde in 0.1 M phosphate buffer at $\mathrm{pH} 7.4$ dechorionated and stained as described by Schulte-Merker et al. (1993).

\section{Histology}

After overnight fixation at ambient temperature in $4 \%$ paraformaldehyde in $1 \times$ PBS, medaka embryos were manually dechorionated, dehydrated, and processed through standard histological methods, including hematoxlin-eosin staining.

\section{Dissection of medaka animal caps}

Mid-blastula-stage medaka embryos (stage 10-11) were incubated for $30 \mathrm{~min}$ in hatching enzyme prepared according to Yamamoto (1975) and dechorionated manually. The animal-most $20 \%$ of the blastula was dissected off in L15 medium (GIBCOBRL) using Tungsten needles. Single animal caps were transferred into agar-coated single wells of a 96-well plate and incubated in $\mathrm{L} 15$ medium at $28^{\circ} \mathrm{C}$ until sister siblings reached the 12-somite stage.

\section{Acknowledgments}

We thank Martin Naegeli for excellent and expert technical assistance, C. Winkler, M. Schartl, D. Grunwald, S. SchulteMerker, U. Lässing, J. Clement, W. Knöchel, Nigel Groome, and Jim Smith for providing key reagents. We are grateful to $\mathrm{K}$. Kirschner and R. Sterner for helpful discussions, and Jay Groppe, M. O'Connel, R. Sterner, M. Rissi, and H. Kataoka for critically reading the manuscript. This work was supported by grants from the Swiss National Foundation, the French Muscular Dystrophy, the Ligue Nationale Centre le Cancer, and the Human Science Frontier Programm to F.M.R., and by a European Molecular Biology Organization fellowship to J.W.

The publication costs of this article were defrayed in part by payment of page charges. This article must therefore be hereby marked "advertisement" in accordance with 18 USC section 1734 solely to indicate this fact.

\section{References}

Albano, R.M., N. Groome, and J.C. Smith. 1993. Activins are expressed in preimplantation mouse embryos and in ES and EC cells and are regulated on their differentiation. Development 117: 711-723.

Amaya, E., T.J. Musci, and M.W. Kirschner. 1991. Expression of a dominant negative mutant of the FGF receptor disrupts mesoderm formation in Xenopus embryos. Cell 66: 257270.

Andersson, S., D.N. Davis, H. Dahlback, H. Jornvall, and D.W. Russel. 1989. Cloning, structure, and expression of the mitochondrial cytochrome P-450 sterol 26-hydroxylase, a bile acid biosynthetic enzyme. I. Biol. Chem. 264: 8222-8229.

Asashima, M., H. Nakano, K. Shimada, K. Kinoshita, K. Ishii, H. Shibai, and N. Ueno. 1990. Mesoderm induction in early amphibian embryos by activin A lerythroid differentiation factor). Wilhelm Roux's Arch. Dev. Biol. 198: 330-335.

Asashima, M., H. Nakano, H. Uchiyama, H. Sugino, T. Nakamura, Y. Eto, D. Ejima, S.-I. Nishimatsu, N. Ueno, and K. Kinoshita. 1991. Presence of activin (erythroid differentiation factor) in unfertilized eggs and blastulae of Xenopus laevis. Proc. Natl. Acad. Sci. 88: 6511-6514.

Bastmeyer, M., B. Schlosshauer, and C.A.O. Stuermer. 1990. The spatiotemporal distribution of N-CAM in the retinotectal pathway of adult goldfish detected by the monoclonal antibody D3. Development 108: 299-311.

Chen, C. and H. Okayama. 1987. High-efficiency transformation of mammalian cells by plasmid DNA. Mol. Cell. Biol. $7: 2745-2752$.

Cooke, I., J.C. Smith, E.J. Smith, and M. Yaqoob. 1987. The organization of mesodermal patterns in Xenopus laevis: Experiments using a Xenopus mesoderm inducing factor. Development 101: 893-908.

Dale, L., G. Howes, B.M.J. Price, and J.C. Smith. 1992. Bone morphogenetic protein 4: A ventralizing factor in early Xenopus development. Development 115: 573-585. 
Dale, L., G. Matthews, and A. Colman. 1993. Secretion and mesoderm-inducing activity of the TGF- $\beta$-related domain of Xenopus Vg1. EMBO J. 12: 4471-4480.

Daopin, S., K.A. Piez, Y. Ogawa, and D.R. Davies 1992. Crystal structure of transforming growth factor-beta2-An unusual fold for the superfamily. Science 257: 369-373.

Fogh, J. and G. Trempe. 1975. New human tumor cell lines. In Human tumour cells in vitro (ed. J. Fogh), pp. 115-159. Plenum Press, New York.

Ge, W., H. Cook, R.E. Peter, J. Vaughan, and W. Vale. 1993a. Immunocytochemical evidence for the presence of inhibin and activin-like proteins and their localization in goldfish gonads. Gen. Comp. Endocrinol. 89: 333-340.

Ge, W., W.J. Gallin, C. Strobeck, and R.E. Peter. 1993b. Cloning and sequencing of goldfish activin subunit genes: Strong structural conservation during vertebrate evolution. Biochem. Biophys. Res. Commun. 193: 711-717.

Gray, K.T., T.C. Flynn, K.M. Gray, and L.M. Nabell. 1987. 17ßestradiol acts directly on the clonal osteoblastic cell line UMR 106. Proc. Natl. Acad. Sci. 84: 6267-6271.

Green, J.B.A., H.V. New, and J.C. Smith. 1992. Responses of embryonic Xenopus cells to activin and FGF are separated by multiple dose thresholds and correspond to distinct axes of the mesoderm. Cell 71: 731-739.

Groome, N. and M. Lawrence. 1991. Preparation of monoclonal antibodies to the beta A subunit of ovarian inhibin using a synthtic peptide immunogen. Hybridoma 10: 309-316.

Gurdon, J.B., S. Fairman, T.J. Mohun, and S. Brennan. 1985. Activation of muscle-specific actin genes in Xenopus development by an induction between animal and vegetal cells of the blastula. Cell 41: 913-922.

Hemmati-Brivanlou, A. and D.A. Melton. 1992. A truncated activin receptor inhibits mesoderm induction and formation of axial structures in Xenopus embryos. Nature 359: 609614.

Herskowitz, I. 1987. Functional inactivation of genes by dominant negative mutations. Nature 329: 219-222.

Holtfreter, J. 1948. Concepts on the mechanism of embryonic induction and its relation to parthenogenesis and malignancy. Symp. Soc. Exp. Biol. 2: 17-48.

Huylebroeck, D., K. Van Nimmen, A. Waheed, K. von Figura, A. Marmenout, L. Fransen, P. De Waele, J.-M. Jaspar, P. Franchimont, H. Stunnenberg, and H. Van Heuverswijn. 1990. Expression and processing of the activin-A/erythroid differentiation factor precursor: A member of the transforming growth factor- $\beta$ superfamily. Mol. Endocrinol. 4: 11531165.

Isaacs, H.V., D. Tannahill, and J.M.W. Slack. 1992. Expression of a novel FGF in the Xenopus embryo. A new candidate inducing factor for mesoderm formation and anteroposterior specification. Development 114: 711-720.

Jones, C.M., K.M. Lyons, P.M. Lapan, W.V.E. Wright, and B.L.M. Hogan. 1992. DVR-4 (bone morphogenetic protein-4) as a posterior ventralizing factor in Xenopus mesoderm induction. Development 115: 639-647.

Kimelman, D., J.A. Abraham, T. Haaparanta, T.M. Palisi, and M. Kirschner. 1988. The presence of fibroblast growth factor in the frog egg: Its role as natural mesoderm inducer. Science 242: 1053-1056.

Kimelman, D., J.L. Christian, and R.T. Moon. 1992. Synergistic principles of development: Overlapping patterning systems in Xenopus mesoderm induction. Development 116: 1-9.

Kimmel, C.B., R.M. Warga, and T.F. Schilling. 1990. Origin and organization of the zebrafish fate map. Development 108: 581-594.

Köster, M., S. Plessow, J.H. Clement, A. Lorenz, H. Tiedemann, and W. Knöchel. 1991. Bone morphogenetic protein 4 (BMP4 ), a member of the TGF- $\beta$ family, in early embryos of Xenopus laevis: Analysis of mesoderm inducing activity. Mech. Dev. 33: 191-200.

Krieg, P.A. and D.A. Melton. 1984. Functional messenger RNAs are produced by SP6 in vitro transcription of cloned DNAs. Nucleic Acids Res. 12: 7057-7070.

Kunkel, T.A. 1985. Rapid and efficient site specific mutagenesis without phenotypic selection. Proc. Natl. Acad. Sci. 82: $488-492$.

Lopez, A.R., J. Cook, P.L. Deininger, and R. Derynck. 1992. Dominant negative mutants of transforming growth factor$\beta 1$ inhibit the secretion of different transforming growth factor- $\beta$ isoforms. Mol. Cell. Biol. 12: 1674-1679.

Luther, W. 1935. Entwicklungsphysiologische Untersuchungen am Forellenkeim: Die Rolle des Organisationszentrums bei der Entstehung der Embryonalanlage. Biol. Zentralbl. 55: $114-137$.

Massagué, J. 1992. Receptors for the TGF-beta family. Cell 69: $1067-1070$.

Nakamura, T., K. Sugino, N. Kurosawa, M. Sawai, K. Takio, Y. Eto, S. Iwashita, M. Muramatsu, K. Titani, and H. Sugino. 1992. Isolation and characterization of activin receptor from mouse embryonal carcinoma cells-Identification of its serine/threonine/tyrosine protein kinase activity. I. Biol. Chem. 267: 18924-18928.

Nieuwkoop, P.D. 1973. The "organization center" of the amphibian embryo: Its origin, spatial organization, and morphogenetic action. Adv. Morphol. 10: 1-39.

Nishimatsu, S.-I., S. Oda, K. Murakami, and N. Ueno. 1992. Multiple genes for Xenopus activin receptor expressed during early embryogenesis. FEBS Lett. 303: 81-84.

Oppenheimer, J.M. 1936. Structures developed in amphibians by implantation of living fish organizer. Proc. Soc. Exp. Biol. N.Y. 34: 461-463.

Ozato, K., H. Kondoh, H. Inohara, T. Iwamatsu, Y. Wakamatsu, and T.S. Okada. 1986. Production of transgenic fish: Introduction and expression of chicken $\gamma$-crystallin gene in medaka embryos. Cell Differ. 19: 237-244.

Roberts, A.B. and M.B. Sporn. 1990. The transforming growth factor- $\beta$ s. In Peptide growth factors and their receptors I (ed. M.B. Sprorn and A.B. Roberts|, pp. 419-472. Springer-Verlag, Berlin, Germany.

Rosa, F.M. 1989. Mix.l, a homeobox mRNA inducible by mesoderm inducers, is expressed mostly in the presumptive endodermal cells of Xenopus embryos. Cell 57: 965-974.

Sambrook, J., E.F. Fritsch, and T. Maniatis. 1989. Molecular cloning: A laboratory manual. Cold Spring Harbor Laboratory Press, Cold Spring Harbor, New York.

Sargent, T.D., M. Jamrich, and I.B. Dawid. 1986. Cell interactions and the control of gene activity during early development of Xenopus laevis. Dev. Biol. 114: 238-246.

Schlosshauer, B. 1989. Purification of neuronal cell surface proteins and generation of epitope-specific monoclonal antibodies against adhesion molecules. J. Neurochem. 52: 82-92.

Schlunegger, M.P. and M.G. Grütter. 1992. An unusual feature revealed by the crystal structure at $2.2 \AA$ resolution of human transforming growth factor- $\beta 2$. Nature 358: $430-434$.

Schulte-Merker, S., R.K. Ho, B.G. Herrmann, and C. NüssleinVolhard. 1993. The protein product of the zebrafish homologue of the mouse $T$ gene is expressed in nuclei of the germ ring and the notochord of the early embryo. Development 116: 1021-1032.

Slack, J.M.W., B.G. Darlington, J.K. Heath, and S.F. Godsave. 1987. Mesoderm induction in early Xenopus embryos by heparin-binding growth factors. Nature 326: 197-200. 
Smith, J.C. 1987. A mesoderm-inducing factor is produced by a Xenopus cell line. Development 99: 3-14.

Smith, J.C., J.M.B. Price, K. Van Nimmen, and D. Huylebroeck. 1990. Identification of a potent Xenopus mesoderm-inducing factor as a homologue of activin A. Nature 345: 729-731.

Smith, J.C., B.M.J. Price, J.B.A. Green, D. Weigel, and B.G. Herrmann. 1991. Expression of a Xenopus homolog of Brachyury $(\mathrm{T})$ is an immediate-early response to mesoderm induction. Cell 67: 79-87.

Smith, W.C. and R.M. Harland. 1991. Injected Xwnt- 8 RNA acts early in Xenopus embryos to promote formation of a vegetal dorsalizing center. Cell 67: 753-765.

- 1992. Expression cloning of noggin, a new dorsalizing factor localized in the Spemann organizer in Xenopus embryos. Cell 70: 829-840.

Smith, W.C., A.K. Knecht, M. Wu, and R.M. Harland. 1993. Secreted noggin protein mimics the Spemann organizer in dorsalizing Xenopus mesoderm. Nature 361: 547-549.

Spemann, H. and H. Mangold. 1924. Über Induction von Embryonalanlagen durch Implantation artfremder Organisatoren. Wilhelm Roux's Arch. Entwicklungsmech. 100: 599638.

Thomsen, G.H. and D.A. Melton. 1993. Processed Vg1 protein is an axial mesoderm inducer in Xenopus. Cell 74: 433-441.

Thomsen, G., T. Woolf, M. Whitman, S. Sokol, J. Vaughan, W. Vale, and D.A. Melton. 1990. Activins are expressed early in Xenopus embryogenesis and can induce axial mesoderm and anterior structures. Cell 63: 485-493.

Vale, W., A. Hsueh, C. Rivier, and J. Yu. 1990. The inhibin/ activin family of hormones and growth factors. In Peptide growth factors and their receptors I (ed. M.B. Sprorn and A.B. Roberts), pp. 211-248. Springer-Verlag, Berlin, Germany.

Weeks, D.L. and D.A. Melton. 1987. A maternal mRNA localized to the vegetal hemisphere in Xenopus eggs codes for a growth factor related to TGF $\beta$. Cell 51: 861-867.

Wittbrodt, J. and W. Erhardt. 1989. An inexpensive and versatile computer-controlled PCR machine using a Peltier element as a thermoelectric heat pump. Trends Genet. 5: 202-203.

Yamamoto, T. 1975. Medaka (killifish), biology and strains. Keigaku Publishing Company, Tokyo, Japan.

Zanetti, M., A. Ratcliffe, and F.M. Watt. 1985. Two subpopulations of differentiated chondrocytes identified with a monoclonal antibody to keratan sulfate. $/$. Cell Biol. 101: 53-59. 


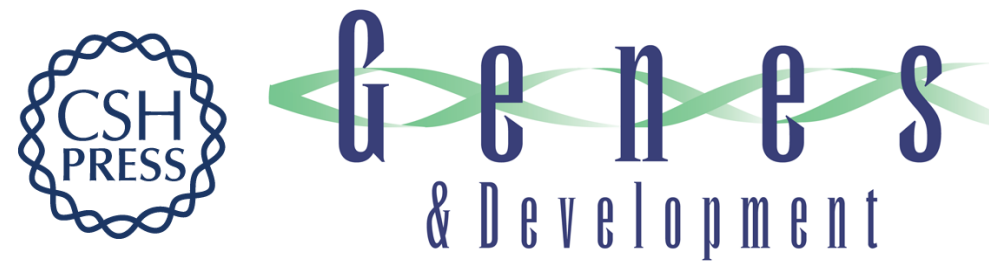

\section{Disruption of mesoderm and axis formation in fish by ectopic expression of activin variants: the role of maternal activin.}

J Wittbrodt and F M Rosa

Genes Dev. 1994, 8:

Access the most recent version at doi:10.1101/gad.8.12.1448

References This article cites 55 articles, 19 of which can be accessed free at:

http://genesdev.cshlp.org/content/8/12/1448.full.html\#ref-list-1

License

Email Alerting

Service

Receive free email alerts when new articles cite this article - sign up in the box at the top right corner of the article or click here.

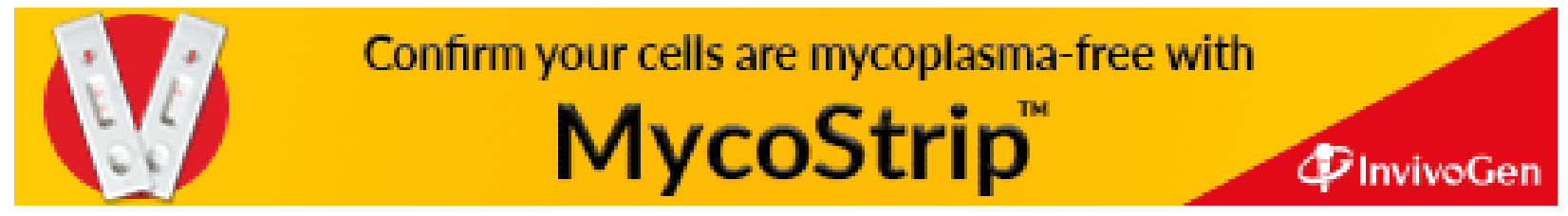

